Fisheries Research

November 2016, Volume 183 Pages 55-73

http://dx.doi.org/10.1016/i.fishres.2016.04.019

http://archimer.ifremer.fr/doc/00339/45048/

(C) 2016 Elsevier B.V. All rights reserved

\title{
Restoring the ecosystem creates wealth. The case of the Northern coast of Tunisia's deep-water rose shrimp trawl fishery
}

\author{
Vendeville Philippe ${ }^{1,{ }^{*}}$, Fadhel Hosni ${ }^{1,2}$, Magraoui Amira ${ }^{1,3,4}$, Sacchi Jacques ${ }^{5}$
}

${ }^{1}$ Institut de Recherche pour le Développement, UMR 248 MARBEC (IRD, Ifremer, Univ. Montpellier, CNRS), Avenue Jean Monnet CS30 171, 34203 Sète Cedex, France

${ }^{2}$ Université de Tunis, Faculté des Sciences, UR/09-04 Biologie, Écologie et parasitologie des organismes aquatiques, Campus Universitaire, El Manar, 2092 Tunis, Tunisia

${ }^{3}$ Université d'Aix Marseille, UFR 939 OSU-Institut Pytheas, Master spécialité Biologie et Ecologie

Marine, Campus de Luminy, 13288 Marseille Cedex 9, France

${ }^{4}$ Ifremer, Laboratoire RH Guyane, Chemin de Suzini, BP 477, 97331 Cayenne, France

${ }^{5}$ FAO Marine Fisheries Management \& Fishing Technology, 331 Chemin du Phare, 34200 Sète, France

*Corresponding author : Philippe Vendeville, email address : philippe.vendeville@ird.fr

\begin{abstract}
:
The demersal trawl fishery of the north Tunisian coast primarily targets the deep-water rose shrimp, Parapenaeus longirostris, and secondarily a variety of demersal fish species. These fishes include hake (Merluccius merluccius), common pandora (Pagellus erythrinus), red mullet (Mullus barbatus), surmullet (Mullus surmuletus), Atlantic horse mackerel (Trachurus trachurus), bogue (Boops boops), picarel (Spicara smaris) and spotted flounder (Citharus linguatula). A bioeconomic model was used to test management measures through scenarios that ran over eleven years to estimate the viability of the fishery according to biological and economic results. The most beneficial scenario was the combination of several management measures including a temporal closure of two months, the replacement of the $40 \mathrm{~mm}$ diamond mesh codend with $40 \mathrm{~mm}$ square mesh, the removal of both the biological recovery tax and of fuel subsidies, and an $83 \%$ reduction in fishing capacity. This results in an annual private profit higher by 9.3 M TND (Tunisian Dinar) (6.9 M USD) that of 2008, and an economic rent that was higher by $13.3 \mathrm{M}$ TND ( $9.9 \mathrm{M}$ USD) than by the end of the projected period. Shrimp and fish biomasses have doubled compared with 2008, and trawling damages would be reduced to the equivalent of a five- fold reduction in fishing effort. This study shows that the objectives of improving demersal ecosystems and improving individual and collective wealth can be achieved through the synergistic effects of various regulatory measures.
\end{abstract}

Keywords : Bioeconomic modeling, Bycatch, Deep-water rose shrimp, Mediterranean shrimp fisheries, Scenarios, Temporal closure 


\section{Introduction}

Since 1996 the global capture of marine fisheries declined before stabilizing at about $80 \mathrm{Mt}$ (FAO, 2014 ), and the overall status of marine stocks has continued to worsen (FAO, 2012b). In 2011, 28.8\% of the stocks were overexploited and $61.3 \%$ were fully exploited (FAO, 2014). In the Mediterranean and Black Sea, the situation is more acute. The production reached a maximum of $1.99 \mathrm{Mt}$ in 1988 in recent years a decreasing trend was apparent: $1.282 \mathrm{Mt}$ in 2012 (FAO, 2014). The main stocks in the Mediterranean and Black Sea are in poor condition. 52\% of assessed stocks were over-exploited and $48 \%$ fully or under-exploited in 2011 (FAO, 2014). 11.2\% of the stocks had collapsed, $33.4 \%$ overexploited, $40.7 \%$ exploited and $14.7 \%$ developing or rebuilding in 
2010 (SAUP, 2016). The demersal resources are subjected to a high fishing pressure from bottom-trawling and artisanal coastal fisheries. According to the Sub-Committee on Stock Assessment (SCSA) of the General Fisheries Commission for the Mediterranean (GFCM), in the Mediterranean, 27 out of 28 of the demersal fish stocks, were overexploited, while only one was under-exploited (FAO/GFCM/CGPM, 2012). In last assessment 22 of the 24 assessed demersal stocks were over-exploited (FAO/GFCM/CGPM/SAC/SCSA, 2015). Among these stocks two affect the Strait of Sicily and the Tunisian bottom trawl fishery studied here: the deep-water rose shrimp and the European hake. Both have been considered over exploited for several years, and for these stocks a reduction in the fishing mortality by 20 to $30 \%$ and by 70 to $80 \%$, respectively, was recommended (FAO/GFCM/CGPM/SAC/SCSA, 2013, FAO/GFCM/CGPM/SAC/SCSA, 2014, FAO/GFCM/CGPM/SAC/SCSA, 2015).

Furthermore it is well established that bottom trawl fisheries have a strong impact on marine ecosystems and biodiversity, and thus on the productivity of other fisheries targeting the incidentally captured species, modifying habitats and species assemblages. Shrimp trawl fisheries, particularly those from tropical areas, are responsible for great quantities of bycatch and discards (Vendeville, 1990, Alverson et al., 1994, Kelleher, 2005, Gillett, 2008, Kelleher, 2008). By comparison, the Mediterranean shrimp fisheries generate less bycatch and fewer discards (Machias et al., 2004, Sacchi, 2008a, Sacchi, 2008b, Zengin and Akyol, 2009).

In the Mediterranean Sea, catches from bottom trawl fisheries are characterized by a large number of commercialized species. Typically, species of high economic value, such as shrimps, are targeted first, while the large remaining portion represents species of lower value, or individuals of small size (Stergiou et al., 2003, Sartor et al., 2003). Consequently, secondarily targeted species and bycatch form a significant contribution to the revenue of bottom trawlers. It is important to distinguish the species landed as secondary targets and discards, which is the portion of the catch that is thrown back to sea. In a recent study these discards in the Mediterranean Sea were estimated at 232,239 $\mathrm{t}$ for 2006, of which 98,085 $\mathrm{t}$ came from the bottom and shrimp trawl fisheries, leading to a discards rate of $35.5 \%$ (Tsagarakis et al., 2014). Local studies in Mediterranean Sea quantified the discards between 14 and $49 \%$ of the total catch (Sánchez et al., 2004, Tudela, 2004), (Damalas and Vassilopoulou, 2011, Ligas et al., 2013, Carbonell et al., 2003). In closer relation to this study, the discard rate of the Italian trawl fishery in the Strait of Sicily is estimated at $49 \%$. Only $0.5 \%$ of deep-water rose shrimp, 5 - 6\% of European hake and 2\% of Atlantic horse mackerel are discarded (Castriota et al., 2001). In southern Tunisia commercial fishes represented $11.4 \%$ of the total discards. The European hake, Red mullet and Common pandora represented $0.3 \%, 0.2 \%$ and $2.6 \%$, respectively, of the total discards. (Jarboui et al., 2005). Trawling also impacts spawning areas and coastal nursery areas, such as sea grass beds, particularly Posidonia oceanica (Sacchi, 2008b). The Mediterranean Sea ecosystem considered as a biodiversity hotspot, is also impacted by other anthropic activities (Bazairi et al., 2010, Durrieu de Madron et al., 2011), as well as by climate change. Such perturbations could modify fish community assemblages, reproductive cycles and seasonal recruitment patterns, and could lead to the arrival of aliens species (Ben Rais Lasram et al., 2010).

From a very early stage the scientific community highlighted the worrying status of Mediterranean fish stocks, recommending a reduction in fishing effort and a multi-specific management approach, particularly for demersal fisheries (Caddy, 1993). The GFCM plays a major role in reaching the objective of restoring the Mediterranean ecosystems. Its principal recommendations are (1) the GFCM/2002/1 to adjust fishing effort for European hake, blue and red shrimp and red mullet (FAO/GFCM/CGPM, 2002); (2) the GFCM/29/2005/1 and the 
$\mathrm{GFCM} / 31 / 2007 / 3$ to improve the selectivity of demersal trawl nets by implementation of a $40 \mathrm{~mm}$ mesh codend (FAO/GFCM/CGPM, 2005, FAO/GFCM/CGPM, 2007); (3) the GFCM/33/2009/2 to adopt a minimum 40-mm square mesh codend or a diamond mesh size of $50 \mathrm{~mm}$ for demersal trawl nets (FAO/GFCM, 2009); the GFCM/34/2010/2 to adjust the overall fishing capacity (FAO/GFCM/CGPM, 2010). The major resolutions are: (1) the GFCM/31/2007/3 for the implementation the $40 \mathrm{~mm}$ square mesh codend in bottom trawling (FAO/GFCM/CGPM, 2007); (2) the GFCM/33/2009/1, where a reduction of at least $10 \%$ of bottom trawl fishing effort is to be applied in all GFCM areas (FAO/GFCM, 2009). Despite the GFCM efforts, limited progress has been achieved regarding the implementation of appropriate fisheries regulations and improvement of stock status to date.

Most often, management regimes were based on biological and exploitation indicators, such as MSY, $\mathrm{F}_{0.1}$, $\mathrm{F}_{\text {current }} / \mathrm{F}_{0.1}$, resulting from single species analysis. When attempting to integrate the maximum number of species impacted by the fishery in multi-specific fisheries, managers faced various conflicting biological objectives. Furthermore management of fisheries is based mainly on biological objectives and the lack of information on the expected effects from socio-economic benefits creates a major barrier to the acceptance and implementation of regulatory measures. It is clearly established that, in order to ensure sustainability of these fisheries, management approaches have to find the optimal compromise that reconciles ecological, economic and social objectives. In the case of fisheries with target species of high economic value, such as shrimp, the problem is particularly acute. Shrimp is the largest commodity sold on global trade in terms of value across all fishery products (FAO, 2012b). High-value species such as shrimp, are extensively traded in prosperous and lucrative export markets, which could have hindered the success of management regulations by encouraging overcapacity within these fisheries (Mc Guire, 1991).

To achieve these goals, bioeconomic models are useful to test the effects of new regulations. Bioeconomic models were used from an early stage in shrimp fisheries such as those in the Gulf of Mexico (Grant and Griffin, 1979, Grant et al., 1981, Blomo et al., 1982), in Northern Australia (Ye et al., 2005, Clark and Kirkwood, 1979, Kirkwood, 1984), in French Guiana (Gilly and Cochet, 1987, Dintheer et al., 1991, Béné, 1997, Chaboud et al., 2008, Chaboud and Thébaud, 2009, Chaboud and Vendeville, 2011) and in Madagascar (Chaboud, 2000, Chaboud, 2008). The bioeconomic approach was also applied in artisanal and multi specific trawl fisheries in the Mediterranean (Lleonart et al., 2003, Merino et al., 2007a, Merino et al., 2007b, Merino et al., 2015, Maynou et al., 2013, Russo et al., 2014). The bioeconomic modeling is developing, however it is not yet truly integrated into the process of drawing up recommendations to fisheries.

This study attempted to estimate the biological and economic impacts of fishery regulations in the case of the Northern Tunisian coastal shrimps trawl fishery. The multispecies approach was favored using a bioeconomic model created using the simulation software Vensim ${ }^{\circledR}$ (Anonymous, 2007) based on an analytical model of the shrimp stock and global models of the eight fish species main unloaded onshore. Simulations were done until 2020 through numerous management scenarios based on the GFCM recommendations, or derivatives thereof (reducing fishing capacity, improving selectivity, closure periods, ...). Some scenarios were run to test the resilience of the fishery to environmental and economic forcings. The results of the simulations were analyzed through biological and economic indicators. 


\section{Case study}

Italian fishers started trawl fisheries in Tunisia. Soon after political independence, the Tunisian government defined territorial waters where only Tunisian boats were authorized to fish and implemented regulatory measures (Anonymous, 1962, Anonymous, 1963b, Anonymous, 1972a, Anonymous, 1972b, Anonymous, 1976, Anonymous, 1994) and in 2005, Tunisia establishes its EEZ (Anonymous, 2005).

In northern Tunisia (Fig. 1) exploitation by bottom trawlers began during the 1980's encouraged by the authorities who were faced with an increasing concentration of trawlers in the Gulf of Gabes (Abdesselem et al., 1998). The northern Tunisian trawl fishery primarily targets the deep-water rose shrimp, Parapenaeus longirostris, because of its high value in European markets. The species is a penaeid shrimp, which is distributed along the eastern and western Atlantic coasts (Takeda and Okutani, 1983, Guéguen, 2000, Crosnier and De Bondy, 1967, Holthuis, 1980) and throughout coastal waters of the Mediterranean basin between $20 \mathrm{~m}$ and 700 m deep over sandy/muddy substrates (Tom et al., 1988, Ardizzone et al., 1990, Chaouachi and Ben Hassine, 1998, Ungaro and Gramolini, 2003, Fiorentino et al., 2008, Sobrino et al., 2005). It is most abundant between depths of $100 \mathrm{~m}$ and $500 \mathrm{~m}$ (Abelló et al., 2002). In 1987 the trawl fleet consisted of 9 vessels, by 1990 it had grown to 10, by 1991 to 29, and by 1995 to 70 (Chaouachi and Ben Hassine, 1998, Ben Meriem et al., 1998). The fishery expanded further in 1999 (Fig. 2), when the landings reached a thousand tons with a fleet of 70 trawlers. Between 2000 and 2011, the annual landings exceeded 1,200 t except in 2005, 2007 and 2008. Since 2009 , the capacity of the fleet has been limited to 70 vessels. Trawlers exploiting the deep-water rose shrimp are based in four harbors where export companies are located: Tabarka, Bizerte, La Goulette and Kelibia. Italian fishers participate in fishing activities through joint-venture companies (Leanza, 1994). Almost all of the shrimp landed in Tunisia are exported (INST, 2012). Spain and Italy are the principal importers of Tunisian crustaceans (Fig. 2). The Tunisian trawlers use two types of bottom trawl: the shrimp trawl and the Italian bottom trawl, both with $40 \mathrm{~mm}$ diamond mesh length in the bag (M'Rabet, 2003). It is important to emphasize that the Tunisian authorities set the $40 \mathrm{~mm}$ mesh size requirement in 1963 (Anonymous, 1963a), while for GFCM this mesh size is only a recommendation (GFCM/CGPM, 2005, GFCM/CGPM, 2007). Many Tunisian trawlers alternately target shrimps or demersal fishes. As a result, in the northern coastal bottom trawl fleet, some vessels have only freezing facilities while others have both freezers and ice holds. The ratio of fish to deep-water rose shrimp landed was initially of at 15 to 1 when exploitation began. However it decreased until it reached 5:1 in 2007. In the case of the Mediterranean shrimp fisheries, fish catch is complementary to the income generated from the targeted shrimp, due to its commercial value. Because the fishing grounds are located in close proximity to the four harbors used by the shrimp trawlers, sea trips are short, lasting two to four days. Bottom trawl fishing activity follows a seasonal pattern with the months of January and September having the lowest activity.

\section{Material and methods}

\subsection{Model objectives}

The bioeconomic model was constructed by adapting to the northern Tunisian shrimp fishery existing models, designed for the shrimp fisheries of Madagascar and French Guiana (Chaboud, 2008, Chaboud et al., 2008, Chaboud and Thébaud, 2009, Chaboud and Vendeville, 2011), 
The main objectives of the model were to represent the dynamics of the fishery in the historical period, between the start of the fishery in 1990 to 2008; and then in the following period from 2009 to the next 11 years, through various scenarios involving external constraints and regulatory measures. The model attempts to provide a representation of the dynamics of the resources of shrimp and fish catch and their contribution to the shrimp fishery development.

Between 2009 and 2019 (projected period), firstly, in order to assess its viability, the fishery is simulated without any changes except a tax established from 2009 to fund a fishing closure in the south zone, the Biologic Recovery Tax (BRT) (Anonymous, 2009); and then, simulations are carried out to assess the fishery's response and resilience to external changes. Two kinds of exogenous changes are introduced: environmental changes, simulating a decrease in shrimp recruitment and specific economic changes such as an increasing fuel price and inflation rate and decreasing the international market price. Finally, the effects of several regulatory measures intended to improve (i) marine resources and ecosystem state; (ii) private revenue and (iii) societal benefit, are analyzed through several scenarios. The regulatory measures relate to the control of fishing effort, seasonal fishing closures, gear modification for improved selectivity and changes in taxes and subsidies.

\subsection{Model structure}

The model was constructed using the Vensim ${ }^{\circledR}$ simulation software (Anonymous, 2007) and is organized in several interconnected modules and based on a daily time step. The main modules are:

- The "Shrimp resource and catch": this module is based on cohort tracking. Owing to sexually dimorphic growth rates of the deep-water rose shrimp, as in all penaeids shrimps, all calculations were performed separately for each sex before aggregating. The module consists of five sub-modules:

- The sub-module "recruitment" integrates the recruitment of each cohort and each sex into the model. The recruits are assumed to enter the exploited phase on the first day of each month. For the calibration period (1990-2008), the time series of the recruitment index was derived from an assessment using VPA. This study used a monthly age class scale rather than an annual scale typically adopted in the majority of stock assessments of this species in the Mediterranean sea (Ben Meriem et al., 1998, Ben Meriem et al., 2010, Ben Meriem et al., 2011, Elouamari et al., 2011). This choice is justified by the short lifespan of the deep-water rose shrimp (a lifespan of 2 to 3 years), by continuous reproduction and recruitment throughout the year following seasonal fluctuations (Ben Meriem et al., 2001, Sobrino et al., 2005), and by the fast and high increase of unit price with age (The price per $\mathrm{kg}$ of shrimps recruited at $13 \mathrm{~mm}$ would be, 22 months later, 13 times higher). The number of recruits of each sex was assessed using a monthly time step and duration of exploitation of 24 months. This was achieved using the XSA method (Shepherd, 1999) and performed with the VPAwin software developed by the Lowestoft laboratory (Darby and Flatman, 1994, Darby, 2003).

- The sub-module "shrimp resources" assesses the standing biomass, the spawning biomass, the natural deaths and the catches, in number and weight per age, using the recruitment data series, the parameters of growth and natural mortality, the length-weight relationship and the catchability for each sex.

- The sub-module "shrimp growth" assesses the individual length, weight and price of shrimps of each cohort and each sex at every time step. The shrimp's price depends on its commercial category (Table 1).

- The sub-module "shrimp catches" provides an assessment of daily catch per sex, age, and cohort, in weight, in number and in value. 
- The sub module "catch structure" assesses the distribution of catches in lengths and in commercial categories at each time step. The calibration of the model was based on the recruitment index time series.

For a given cohort of shrimp $c$ of a given sex, recruited at $t=c$, the number of individuals $N_{c, a+1, t}$ at age $a+1$ at time $t+1$ is:

$$
N_{c, a+1, t+1}=N_{c, a, t} \cdot e^{-Z_{a, t}}
$$

and at $t=c, a$ is the age of recruitment $a_{r}$ :

$$
N_{c, a_{r}, c}=R_{c}
$$

where $R_{c}$ is the recruitment of the cohort $c$.

If $Z_{t}$, is the total instantaneous mortality, $F_{t}$ and $M_{t}$ are the fishing and natural mortalities,

$$
Z_{c, a, t}=F_{c, a, t}+M_{c, a, t}
$$

where

$$
F_{c, a, t}=q_{c, a, t} \cdot f_{t}
$$

where $f_{t}$ is the nominal effort developed by the fleet, the day $\mathrm{t}$.

The day $t$, the catch in number is:

$$
C_{c, a, t}=N_{c, a, t} \cdot F_{c, a, t} \cdot \frac{1-e^{Z_{a, t}}}{Z_{a, t}}
$$

and catch in weight is:

$$
y_{c, a, t}=C_{c, a, t} \cdot w_{a}
$$

where $w_{a}$ is the individual weight at age $a$,

$$
w_{a}=\propto . L c_{a}^{\beta}
$$

and the carapace length at age a, $L c_{a}$ is:

$$
L c_{a}=L c_{\infty} \cdot\left(1-e^{-K \cdot\left(a-a_{0}\right)}\right)
$$

where $L c_{\infty}$ is the asymptotic carapace length and $K$ is the growth coefficient.

The total daily catch is the sum of catches of cohorts present at time $t$ :

$$
Y_{t}=\sum_{c} y_{c, t}
$$

It should be noted that the standing cohort's biomass at $t$, is:

$$
B_{c, a, t}=N_{c, a, t} \cdot w_{a}
$$

At $t$, the daily catches $Y_{t}$ of all cohorts present are spread in $p$ commercial categories $Y_{k, t}$ according to their individual weight:

$$
Y_{t}=\sum_{k=1}^{k=p} Y_{k, t}
$$

If $\gamma_{k, t}$ is the unit price of the category $k$ at the date $t$, the value of the daily shrimp catch is: 


$$
V s_{t}=\sum_{k=1}^{k=p} \gamma_{k} \cdot Y_{k, t}
$$

The value of the daily bycatch for export, $V b c e_{t}$, is:

$$
\text { Vbce }_{t}=\mu \cdot V s_{t}
$$

where $\mu$ is a ratio derived from a survey of export companies. The total value of daily catch for export is:

$$
V \exp _{t}=V s_{t}+V b c e_{t}
$$

- The "Fish resource and catch" module, assesses the current biomass and the catch for a selection of eight fish species at each time step, using a Schaefer model. The species considered are: European hake (Merluccius merluccius), common pandora (Pagellus erythrinus), red mullet (Mullus barbatus), surmullet (Mullus surmuletus), Atlantic horse mackerel (Trachurus trachurus), bogue (Boops boops), picarel (Spicara smaris) and spotted flounder (Citharus linguatula). These species are the main secondary target species and represented 62 to $81 \%$ of the total fish bycatch landed by the trawl fishery of the northern coast of Tunisia between 1995 and 2010 .

For a species $i$, the population biomass $B_{i}$ is:

$$
\begin{gathered}
B_{i}=B_{i}+\frac{d B_{i}}{d t}-\frac{d y_{i}}{d t} \\
\frac{d B_{i}}{d t}=B_{i} \cdot r_{i} \cdot\left(1-\left(\frac{B_{i}}{K_{i}^{\prime}}\right)\right) \\
\frac{d y_{i}}{d t}=q_{i} \cdot \frac{d f}{d t} \cdot B_{i}
\end{gathered}
$$

where $r$ is the intrinsic growth rate, $K^{\prime}$ is the carrying capacity of the population and $y$ the catch.

For a short time interval, such as the time step used here, this expression is approximated with:

$$
B_{i, t}=B_{i, t-1}+B_{i, t-1} \cdot r_{i} \cdot\left(1-\left(\frac{B_{i, t-1}}{K_{i}^{\prime}}\right)\right)-y_{i, t}
$$

where

$$
y_{i, t}=q_{i} \cdot f_{t} \cdot B_{i, t-1}
$$

The parameters $K_{i}^{\prime}, q_{i}$ and the value $B_{i, 0}$ are necessary to initiate the calculation; they are assessed using the solver function in Microsoft Excel, minimizing the square-deviations between the monthly catches computed and the monthly catches reported.

The daily catch value for the species $i$, is:

$$
v_{i, t}=\gamma_{i, t} \cdot y_{i, t}
$$

where $\gamma_{i, t}$ is the unit price of the species $i$

The species specific total daily fish catch value $V f_{t}$ is:

$$
V f_{t}=\sum_{i} v_{i, t}
$$


- The "Economic parameters" module is organized in three sub-modules :

- The sub-module "Shrimp and Fish market" calculates the value of shrimps according to their commercial categories (Tab. 1) and the value of fish bycatch during each time step. This sub-module interacts with the two previous modules.

- The sub-module "Fleet exploitation costs" calculates the costs and subsidies at each time step. The intermediate costs, $C I$, and the labor cost, $C L$, are distinguished within the costs. The intermediate costs are divided between fixed costs and variable costs. Fixed costs, $C F$, are the annual or monthly charges; they are dependent on the number of fishing units present at the beginning of the year: mooring, insurance, licenses, maintenance and depreciation of capital (vessel hull, engine, fishing gear, electronic material). Variable costs $C V$ are proportional to effort e.g. number of days at sea, (fuel cost, a share of repairs, oil, lubricant, refrigerant or ice, food on board, etc.) and proportional to the catch volume, e.g. processing cost, or depending on production value, (BRT). The main subsidy is the government contribution to fuel expenditure, and as such it acts on the fuel cost and is included in this cost.

The total of intermediate costs $T C I$, during the year $y$, for the fleet consisting of $n_{y}$ boats, is:

$$
T C I_{y}=n_{y} \cdot C F_{y}+\sum_{t 0_{y}}^{\operatorname{tmax}_{y}} C V_{t}
$$

where $t 0_{y}$ and $\operatorname{tmax}_{y}$ are the first and last day of the year $y$ respectively

The total of all costs $T C_{y}$ is:

$$
T C_{y}=T C I_{y}+C L_{y}
$$

- The sub-module "Fleet economic results" computes the revenue composed of shrimp catch value and of bycatch value at each time step. Bycatch has two components: the fishes for the national market and bycatch for export composed of other shrimp species, lobsters and cephalopods. A ratio between the value of bycatch for export and the value of deep-sea rose shrimp was assessed using surveys of export companies. This submodule provides values of annual economic indicators: total catch value, company profits, state revenue, added value and economic rent. This last economic indicator represents the wealth production for the civil society.

The revenue of the daily total catch, $T V_{t}$, is:

$$
T V_{t}=V \exp _{t}+V f_{t}
$$

and the annual revenue, $T V_{y}$, is:

$$
T V_{y}=\sum_{t 0 \_y}^{t m a x \_y} T V_{t}
$$

The private profit of the fleet, $P P_{y}$, is:

$$
P P_{y}=T V_{y}-T C_{y}
$$

The state revenue in a year, $S R_{y}$, is:

$$
S R_{y}=T T_{y}-T S_{y}
$$

where $T T_{y}$ is the sum of taxes received during the year and $T S_{y}$ the sum of the subsidies. 
The economic rent $E R_{y}$ is:

$$
E R_{y}=P P_{y}+T T_{y}-T S_{y}
$$

The net added value, $A V_{y}$, is:

$$
A V_{y}=T V_{y}-T C I_{y}
$$

- The "Dynamics of fishing capacity" module deals with fishery closures and the breaks in fishing activity when the quota is reached. It also adjusts the fleet capacity during the projected period (starting in 2009); the fleet dynamic is based on the private profit rate of the preceding year which leads to entry or exit of fishing units, or a stand-by situation (Smith, 1969).

The variation of the fleet capacity, $N b$, between the years $y-1$ and $y$ depends on the profit rate, $\tau$, on the opportunity cost, $\kappa$, and on a sensitivity rate, $s$.

$$
\begin{gathered}
\tau_{y}=\frac{P P_{y}}{T C_{y}} \\
\begin{cases}\frac{\Delta N b}{N b_{y-1}}=\left(\tau_{y-1}-\kappa\right) \cdot s_{1} & \left(\tau_{y-1}-\kappa\right) \geq 0 \\
\frac{\Delta N b}{N b_{y-1}}=\left(\tau_{y-1}-\kappa\right) \cdot s_{2} & \left(\tau_{y-1}-\kappa\right)<0\end{cases}
\end{gathered}
$$

In this model, the opportunity cost, $\kappa$, is fixed at 0.05 and the sensitivity rates $s_{1}$ and $s_{2}$ are fixed at 0.50 .

When the fishing effort is controlled, and $N b_{\max }$ is the maximum number of boats authorized to operate, the following condition is required:

$$
N b_{y}+\Delta N b \leq N b_{\max }
$$

\subsection{Model specification}

\subsubsection{Biological inputs}

The majority of the parameters required for modeling both the deep-water rose shrimp and fish resources and their exploitation come from the Marine Fisheries and Aquaculture General Direction (DGPMA). These include the monthly landings between 1995 and 2010, and the monthly fishing effort (capacity, numbers of days fished) between 1995 and 2008. For the period 1990-1995, parameter values are derived from previous studies (Chaouachi and Ben Hassine, 1998, Ben Meriem et al., 1998). The landings data provided by DGPM are corrected by a factor of $17 \%$ to compensate for under-reporting caused by transshipments, illegal-markets, etc. (Halouani et al., 2015). Discards of shrimps and of the eight fish species selected were neglected in this version of the model. Low discards rates are reported in the Strait of Sicily for these species (Castriota et al., 2001) along with the low values reported in Northern Tunisia (Jarboui et al., 2005). Any introduced bias following this assumption is likely to be minor. The seasonal pattern of fishing effort is implemented in the projection period with maximum effort in March-July and minimum effort in August-February.

Shrimp growth parameters, length-weight relationship, natural mortality and size at first maturity used in this study were obtained from studies carried out in the area (Table 2) and the majority of those adopted here are used in GFCM's Stock assessment group for the area (Ben Meriem, 1993, Ben Meriem et al., 2010, Ragonese et 
al., 2004). The parameters of the selectivity curve are derived from a variety of studies (M'Rabet, 2003, Gharbi et al., 2004, Guijarro and Massutí, 2006, Ragonese and Bianchini, 2006).

The greatest difficulty encountered when fitting a bioeconomic model was due to a lack of length frequency data from monthly catches, which is essential for assessing monthly recruitment per sex. To overcome this major obstacle, a data set was built based on the monthly length frequencies observed in the Straits of Sicily between 1989 and 1990 (Levi et al., 1995) along with a mean annual sex-ratio per length class relationship. The method is detailed below.

- method:

If $x_{i, m, y}$ is the number of shrimps of both sexes of carapace length class $i,\left[\mathrm{CL}_{i}, \mathrm{CL}_{i+l}[\right.$, of the month $m$, of the year $y$ then:

$$
x_{i, m, y}=x_{i, m, y r e f} \cdot \frac{W_{m, y}}{W_{m, y r e f}}
$$

where $W_{m, y}$ is the total weight of the catch for month $\mathrm{m}$ of the year $y$ and $y r e f$ is the year of reference.

And then, If $x_{\odot, i, m, y}$ and $x_{\widehat{\wp}, i, m, y}$ are the number of female and male shrimps respectively of the carapace length class $i\left[\mathrm{CL}_{i}, \mathrm{CL}_{i+1}[\right.$, of the month $m$, of the year $y$ :

$$
x_{\varphi, i, m, y}=x_{i, m, y} \cdot \rho_{i} \text { and } x_{\sigma^{\top}, i, m, y}=x_{i, m, y} \cdot\left(1-\rho_{i}\right)
$$

where $\rho_{i}$ is the mean sex ratio for the carapace length class $i\left[\mathrm{CL}_{i}, \mathrm{CL}_{i+1}[\right.$.

In this form, the assessment of number of shrimps per length class is biased due to the difference between length-weight relationship of females and males, and thus requires correction.

The corrected number of shrimp for length's class I, $x_{+, i, m, y}^{\prime}$ and $x_{\sigma^{\prime}, i, m, y}^{\prime}$ is:

$$
x_{+, i, m, y}^{\prime}=a_{m, y} \cdot x_{\uparrow, i, m, y} \text { and } x_{\delta^{\gamma}, i, m, y}^{\prime}=a_{m, y} \cdot x_{\delta, i, m, y}
$$

where $a_{m, y}$ is :

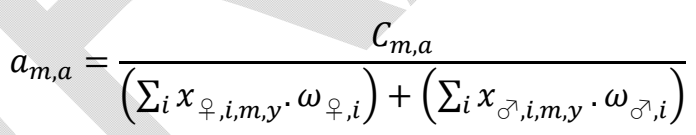

Where $\omega_{\varphi, i}$ and $\omega_{\sigma^{7}, i}$ represent the mean individual weight of females and males of carapace length class $i$, $\left[C L_{i}, C L_{i+1}[\right.$, respectively.

- Validation of the method :

To ensure the strength of this method and its fitting quality, it was initially tested using an existing case study: the French Guiana's shrimp fishery for which a length frequency data set obtained through a rigorous sampling regime was available. This dataset collected between 1994 and 2007 contained 324,471 measurements of females and 163,506 of males. The monthly length frequencies per sex were calculated according to the method described above, using 1994 as a reference year and followed by a VPA-XSA, performed to compute the recruitment index. Then the simulated recruitment series obtained from the new length frequencies data set were compared with the recruitment series obtained from real length frequency data.

Then the method was applied to the length frequency data from the deep-water rose shrimp fishery in the Sicily Channel provided by Levi (Levi et al., 1995), in order to use it in the recruitment assessment for this study. The VPA-XSA analysis was performed over the 1990-2008 period, after which, the necessary data on fishing effort 
was unavailable at the time of the study. During two last years of the calibration period 2007-2008 the assessments of monthly recruitments had not yet converged and, as a result, we assume their values to be the averages of monthly recruitments between 2000 and 2006. Likewise, for the simulation period, up to 2009, the recruitment was also based on the mean pattern of the time series between 2000-2006.

Modeling the dynamics of fish resources was based on the Schaefer model applied to the eight selected species. For each species a model was fitted to the 1995-2008 period, when landings and effort data series were available, using the least squares method.

\subsubsection{Economic inputs}

An economic survey was carried out with skippers, fishing companies and export companies between December 2011 and May 2012. A total of 40 questionnaires were returned. This survey provided information on vessel characteristics (e.g., gross tonnage, engine power, storage capacity, freezing capacity); fishing area exploited; general fixed costs (e.g., insurance, mooring costs, hull, engines, winches, electronic equipment and fishing gear writing off and replacement costs; variable costs, such as food expenses and supply, fuel and lubricant consumption, sodium metabisulfite or melacide consumption, packaging costs, crew salaries, and company remuneration (percentage of the shared revenue), part of the shared expenses (Table 3). An international reference study (Ebert et al., 2009) provided a series of fuel price between 1991-2008 while official announcements were used for more recent years.

All values of costs and prices collected are based on the 2009-2010 period with the exception of the fuel and the shrimp prices. Because the model requires current values at each time step, the values collected were transformed using an annual consumer prices index with a base of 100 in 2009 from data provided by the National Institute of Statistics of Tunisia (INST, 2010, INST, 2011).

The fuel price, the consumer price index and the shrimp export prices are assumed to have remained constant since the last data were available, in April 2013, December 2012 and December 2009, respectively.

These costs are around those reported in literature. In 2005 the total costs per ton of reported catch amounted to 2,076 USD (real US\$ 2005), that is $66 \%$ more than the mean value reported in Africa and $38 \%$ more than in Europe but less that in Oceania (Lam et al., 2011) This additional cost results come from higher costs in trawl fleets. The portions related to fuel and labor costs represented $30 \%$ and $38 \%$ respectively of the total variable fishing costs similar those reported in the previous study. The higher costs compared with those of a study on the Turkish Marmara Sea shrimp trawler fishery (Güngör et al., 2007) were due to the Tunisian fleet, to the greater engine power, as well as longer fishing cruises. The fuel consumption in the Tunisian fleet in particular is 30 times higher, values similar to those reported for French trawl fisheries (Planchot and Daures, 2008).

The prices per commercial category paid to fishers by export companies during the 2009-2010 period were known (Table 1). It was assumed that during the calibration period the prices followed the same trend as the export price of shrimp from Tunisia, regardless of the commercial category, across all species and categories combined, in accordance with statistics provided by the FAO (FAO, 2012a). An index of shrimp export price was calculated from these statistics and translated in current TND, with base value of 100 in 2009.

The economic parameters at each time step are given in the current TND value. Nevertheless in order to remove the inflation effect, the synthetic parameters used in the present analysis were converted to constant TND. 


\subsubsection{Main outputs}

The objectives of the current study focused on the following indicators:

- the number of active fishing vessels in order to incorporate the social impact and particularly the significance of the shrimp fishery in terms of job creation;

- The standing stock biomass of shrimp and fish in order to gauge their capacity for ecosystem restoration;

- The private profit in order to measure the wealth generated for fishers and companies; the private profit must be positive for a fishery to be viable;

- The economic rent, in order to determine the revenue produced by the fishing activity for the society at large. When the rent is negative fishing activities represent a cost to society. Conversely, when the rent is positive, the activity improves the collective wealth;

- The added value, in order to determine the effective wealth created by the activity; an added value is positive when the value of the product increases;

- The state revenue, in order to determine the degree of financial assistance from governmental authorities. When the state revenue is negative, the community is paying for the fishery activity. When it is positive, the fishery sector is self-sufficient.

\subsection{Sensitivity of the model}

Model sensitivity to various input parameters is tested using a Monte Carlo simulation with a random uniform distribution between values of $\pm 10 \%$ and 200 iterations.

\subsection{Choice of scenarios}

An initial series of scenarios were selected to test the response of the fishery under exogenous changes and compared to the reference scenario $(\mathrm{H} 0)$ :

- A 25\% decrease in recruitment in one year, 2009 ( $\mathrm{Hr} 1$ ). It is well known that the stocks of penaeids shrimps are subjected to high variations in recruitment (Garcia and Le Reste, 1981, Ehrhardt and Legault, 1999, Thomson, 1955);

- A progressive decrease of $4 \%$ per year in recruitment from 2009 ( $\mathrm{Hr} 2$ ). This case was observed in some penaeid fisheries, such as on the Campeche Bank in the Gulf of Mexico (Ramirez Rodriguez et al., 2006, Ramirez-Rodriguez and Arreguin-Sanchez, 2003, Arreguin-Sanchez et al., 2008);

- An increase in the price of fuel by 0.080 TND (0.06 USD) per year and an increase in the consumer price index by 4 points per year, from 2010 (He 1). This scenario is realistic in comparison to trends observed since 2000 (INST, 2010);

- A decrease in the index of the export price of shrimp by 2 points per year (He 2). Such fluctuations were observed between 2000 and 2005 in the globally important international market place in Tokyo (FAO, 2012b),

- Finally, combining two or three of the previous changes.

The second type of scenario selected is a response to current propositions or recommendations of the GFCM or its Scientific Advisory Committee and in the case of the fishing effort reduction, in response to the Resolution GFCM/33/2009/1 (FAO/GFCM, 2009).

- A reduction in fishing effort. A fishing effort reduction was implemented in 2009 over several stages, gradually decreasing by steps ranging from $5 \%$ to $100 \%$. 
- A change in fishing gear, substituting the current $40 \mathrm{~mm}$ diamond mesh with a $40 \mathrm{~mm}$ square mesh.

- A closed season. Two durations were tested: one month and two months. These closures implemented in 2012 were tested for each month with the initiation set at the start of each month of the year.

- A decrease in fuel subsidies or their complete removal and an abolition of the BRT in 2009.

- Combining several measures and testing the fishery responses to exogenous changes under these scenarios.

\section{Results}

\subsection{Shrimp recruitment dataset}

The preliminary examination of the method for building a dataset of monthly lengths frequencies through the case study of French Guiana showed that for each sex the recruitment index series obtained was very similar to that computed from the observed monthly lengths frequencies, with a regression analysis producing an $\mathrm{R}^{2}$ value of 0.60 for females and 0.69 for males (Fig. 3). The method was considered consistent and was applied to Tunisian trawling fishery.

\subsection{Calibration of simulated catches}

The model showed a good fit during the 1992-2006 period. Between 1990 and 1992, a major discrepancy was observed between simulated shrimp catches and the observed values due to the model's requirement of the first 24 cohorts to be available for a complete representation of the exploited shrimp stock. As indicated above, a discrepancy is also evident after December 2006, because the numbers of recruits were not assessed by VPAXSA but were instead derived from means of the monthly recruitment during the 2000-2006 period. In terms of the calibration period, between 1992 and 2006, the quality of the fit of monthly shrimp catches appears to be good (Fig. 4a) with a coefficient of determination of 0.97 .

The fit of the fish catch, based on Schaefer's model, is less accurate than that of shrimp catch from the VPAXSA due to the quality of this population dynamic model type, the values of coefficients of determination of the models for the hake and for the eight species of fishes were 0.35 and 0.39 respectively. Nevertheless, the resulting sum of the eight species of fishes effectively describes the trends in observed catches between 1995 and 2008 (fig. 4b).

\subsection{Reference scenario and sensitivity of the model}

In the reference scenario, during the first four years of the projected period, the capacity of the fleet increases from 85.3 fishing units to 88.3, and from 2013 decreases slowly to reach 80 fishing units by 2019 (Fig. 5a and $5 b)$.

During the first five years of the calibration period, when the fishery became established, the annual private profit shows a low positive value (Fig. 5c). The poor economic results obtained in 2005 and 2007 are due to a large decrease in recruitment which occurred in 2004 and 2006, decreasing by $17 \%$ and 34\%, respectively, when compared to the previous year. In the projected period, the implementation of the BRT in 2009 impacts the private profit, which decreases from 2011 until 2019, reaching values below 100,000 TND (74,000 USD) after 2015. The added value (Fig. 5d) and the economic rent (Fig 5e) follow the same trend.

The dynamic of fish biomass during the projected period explains why the fleet continues its expansion; the decrease in the fleet's capacity arises when the fish biomass reaches too low a level. 
The annual private profit appeared more sensitive to uncertainties on parameters $\mathrm{M}$ and $\mathrm{K}$ than the shrimp biomass due to combined effects of catch-length structure and the prices of commercial categories. Consequently, the dynamics of fishing capacity and fish biomass are also sensitive to these parameters during the projected period. (Fig. 6).

\subsection{Fishery responses to exogenous changes}

\subsubsection{Recruitment forces}

The variations of the main indicators in the three scenarios (fig. 7) suggest that the fishery has a good resistance to rapid reduction in recruitment for a limited time ( $\mathrm{Hr} 1)$ because the exploited phase is twice as long as the reduction. It should be noted that such a situation occurred in 2005 and again in 2007. In contrast, a gradual decrease in recruitment of $4 \%$ per year leads to negative private profits from 2013 onwards, meaning that the fishery begins to collapse and is going bankrupt. The fleet reacts to the drastic reduction by increasing capacity slower than in the reference case $\mathrm{H} 0$, but the dynamics in both situations are very similar. In the scenario $\mathrm{Hr} 2$, the capacity declines five year after the start of the recruitment decrease. These two scenarios of changing recruitment had little impact on fish biomass, likely a result of the long response time, which allowed the fleet capacity to adjust.

\subsubsection{Exogenous economical forces}

Three scenarios are explored: He 1, He 2 and the third scenario combining both previous economic forces together $(\mathrm{He} 1+2)$. Only the fleet and private profit are presented (Fig. 7e and 7f). Biomass values approximate those of the reference scenario $\mathrm{H} 0$, in the forks $[-0.5 \%,+3.3 \%]$ for the shrimps, and $[-1.3 \%,+2.2 \%]$ for the fishes, respectively, with scenario He 1 leading to the lowest biomasses. An increase in the fuel price and the consumer price index induces increases in fleet capacity and in private profit; the two alternative scenarios lead to decreases in fleet capacity and in private profit. These results confirm the compensatory role of fish catches in the fishery's economic results. Indeed an increase in the local consumer price index induces an increase in fish price on the national market, while a depreciation of the international market price of shrimp is not compensated.

\subsubsection{Combining recruitment and economic forces}

In the previous economic situations, if the recruitment decreases by $4 \%$ per year from 2009 , a zero private profit is reached one year earlier when the export price decreases ( $\mathrm{Hr} 2$ and $\mathrm{He} \mathrm{1+2).} \mathrm{Alternatively,} \mathrm{under} \mathrm{the} \mathrm{last}$ scenario zero profit is reached two years earlier due to the removal of vessels from the fishing fleet being more important (Fig. $7 \mathrm{~g}$ and $7 \mathrm{~h}$ ).

\subsection{Fishery response to management regulations}

\subsubsection{Reducing the fishing effort}

According to the values obtained during the last year of the projected period (Fig. 8), both annual shrimp landings and fish landings are weakly affected by a reduction in fleet capacity; a decrease of $1 \%$, from the reference scenario, requires a 50\% reduction in capacity while a decrease of $10 \%$ requires a $75 \%$ reduction in capacity. In contrast, the biomass of fishes increases, reaching the highest level observed during the historic period (26,700 $\mathrm{t}$ in 1998), following a 50\% reduction in fleet capacity. Economic indicators increase until 
capacity is reduced by $85 \%$. A reduction of $10 \%$ in capacity would achieve a positive net added value, and a reduction of $25 \%$, a positive economic rent. A reduction of at least $20 \%$ in fleet capacity is necessary while reductions up to $85 \%$ are beneficial to the economic outcomes of the fishery, to the community and to the restoration of the ecosystem.

\subsubsection{Mesh regulation}

The adoption of a $40 \mathrm{~mm}$ square mesh instead of a $40 \mathrm{~mm}$ diamond mesh, in the absence of any other measure, produces minor improvements across most indicators in the final year, with the exception of private profit which is $39 \%$ greater than the reference scenario. Increasing capacity at the beginning of the simulation period to a level slightly higher than in the reference scenario reduces the expected effect of the change in mesh shape, resulting in a fish biomass that is $1 \%$ lower than that of the reference scenario. Furthermore, the added value and the economic rent decrease by $2 \%$ and $3 \%$ respectively.

When this measure is associated with a $10 \%$ decrease in fishing capacity, as stated in the GFCM resolution GFCM/33/2009/1, the shrimp biomass, the fish biomass, the private profit and the economic rent are significantly higher than in the reference scenario, however the downward trend in these four indicators during the last years of the simulation period is not reversed (Fig. 8c and 8d).

\subsubsection{Temporal closures}

When compared with the reference scenario without closures, most indicator values are higher at the end of the projected period (Fig. 9). Exceptions were the total biomass and the spawning biomass of shrimp, for which the values were inferior for closures during the first six months, as well as shrimp landings, which were lower for closures at the beginning and at the end of the year. For both closure durations, the value of annual private profit is higher than when no closures are introduced and so too is the fleet capacity. Two factors contribute to the improvement of the economic outcomes: the closure modifies the length and weight composition of both the shrimp population and of the catch, when fishing starts again the mean price of shrimps landed is increased (Fig. 10); the closure slows down or stops the reduction of fish biomass (Fig. 9d and 9e) and, as a result, the fish landings are higher than in the scenario without closures. Although closure measures appear more effective than that of changing the mesh shape, their effect on fish biomass, profit, added value and economic rent are rather weak. Without controlling the fleet capacity, the positive effect of this regulation on the profit causes new entries into the fishery, reducing the expected effects that the measure had when applied alone.

\subsubsection{Taxes and subsidies as management tools}

In the previous scenarios, the annual economic rent is negative because the state subsidies are drawn from it, unless the fleet capacity is reduced by at least $25 \%$. The removal of the fuel subsidy insures a positive economic rent from the first year of the projection, but leads to negative private profit values from the first year of projection and for each year from 2010 onwards, one or two boats are removed from the fleet. This measure, applied in isolation, does not allow for a viable fishery.

The removal of the biological recovery tax has a positive effect on private profit, particularly during the first five years of the projection. The private profit is $8 \%$ higher in the final year compared with that of the reference scenario, while the economic rent is $10 \%$ lower and biomass of shrimp and of fish are $1 \%$ and $2 \%$ lower, 
respectively, due to a minor increase fleet capacity $(2 \%)$. The impact of this measure is insignificant when compared to the reference scenario.

\subsubsection{Combined measures}

In cases of fishery closure implemented from 2012 the stakeholders had expressed preference for DecemberJanuary or May-June. These closure periods are tested in combination with a $25 \%$ or $50 \%$ reduction in capacity, mesh shape modification, biological recovery tax removal and fuel subsidy reduction from $30 \%$ to $20 \%$ from 2009. Among these four groupings of measures, the combination of a May-June closure and $50 \%$ capacity reduction leads to the best biological and economic results at the end of the projected period. Nevertheless the state's contribution remains an important factor, even if the deficit is reduced by a factor of 2-3 (Tab. 4). The different measures act in synergy, particularly on the distribution of catch per commercial category (Fig. 10), where the contribution of small shrimps of low value decreases, while shrimps of greater sizes (categories $\mathrm{O}$ to OOOO) become more important, increasing the economic value of the catch. Consequently, at the end of projected period, the mean price of shrimp reaches 12.842 TND. $\mathrm{kg}^{-1}$ (9.52 USD. $\mathrm{kg}^{-1}$ ) under the May-June closure set with a $50 \%$ capacity decrease, while it is 6.935 TND. $\mathrm{kg}^{-1}$ (5.14 USD. $\left.\mathrm{kg}^{-1}\right)$ under the reference scenario, and 7.761 TND. $\mathrm{kg}^{-1}$ (5.75 USD. $\mathrm{kg}^{-1}$ ) when the mesh was changed in conjunction with a $10 \%$ capacity decrease; when compared with each other, these scenarios result in an increase in the mean price of $85 \%$ and $65 \%$, respectively.

In order to drive the state revenue towards positive values the complete removal of fuel subsidies is implemented instead of decreasing it by $20 \%$. The fuel subsidy deletion is an unpopular measure, nonetheless its removal did not affect the fleet capacity or the biomass of shrimp or fish. In comparison with a $20 \%$ reduction in the fuel subsidy, the private profit is only marginally affected $(-7 \%)$ while the economic rent is improved $(+8 \%)$. When compared with the reference scenario, the set of biological and economic indicators are improved (Fig. 11, Tab. 4).

The biological and economic responses to exogenous forces $(\mathrm{Hr} 2$, He 1+2) are tested under two sets of combined measures: first with a closure in May-June and a $20 \%$ fuel subsidy (set $\mathrm{d}$ and $\mathrm{f}$ ) and second with the fuel subsidy removed and the capacity reduced by $50 \%$ (set $\mathrm{h}$ ). In these two cases, private profit is positive until the end of the projected period, whereas in the reference scenario, the private profit becomes negative from 2013 onwards (Fig 11e). When capacity is decreased by 25\%, the economic rent reaches a negative value in 2018; in the other cases this indicator is positive throughout the projected period, whereas under the reference scenario, the value of the economic rent is negative from 2008 and throughout the projected period (Fig 11f). These results suggest an improved viability of the fishery when such regulations are applied.

The negative impacts of the bottom trawling on the ecosystems are well known and national states regularly attempt to reduce this fishing practice. Various levels of capacity reduction were tested here. The highest values of private profit and economic rent are obtained following a $82.5 \%$ reduction in capacity. In this situation the shrimp biomass recovers to the maximum value observed during the calibration period after 8 months while the equivalent recovery in fish biomass (the eight species) takes 4.25 years. At the end of the simulated period, the biomasses of both shrimp and fish are more than twice as high as those at the end of the calibration period. The private profit in the last year of the projected period is more than five time its value from the last year of the calibration period as shrimps of larger sizes contribute $41 \%$ to the total landings in weight, and $72 \%$ in value. 


\section{Discussion}

According to our model this set of measures would multiply the private profit by six times compared with that at the end of the calibration period, and twice that of the historic peak of the fishery. Furthermore the biomass of the most landed fish species would reach, or exceed, their levels observed during the calibration period.

In most of the scenarios the economic results obtained are in accordance with observed practices in Mediterranean bottom trawl fisheries where fish catch compensates for reduced shrimp catches (Abdesselem et al., 1998, Zengin and Akyol, 2009).

The regulation combining a 10\% reduction in fishing capacity and the implementation of square mesh, would be consistent with the GFCM recommendations (GFCM/2002/1, GFCM/29/2005/1, GFCM/31/2007/3, GFCM/33/2009/2, GFCM/34/2010/2) and the resolutions (GFCM/31/2007/3, GFCM/33/2009/1) but completely useless for improving ecosystems and fishery revenues. With this regulation, the shrimp biomass increases slightly until 2011 and then decreases; the process of fish biomass degradation is slowed but continues. Annual private profit is positive, but rather low and decreases from 2011 while annual economic rent, remains in deficit, despite an improvement. Thus, this regulation does not appear sufficient to achieve the objectives of restoring the demersal fish resources while ensuring the viability of the fishery.

According to the Common Fishery Policy (CFP) for the Mediterranean Sea (EC, 2006), and the Management Plan for the Italian Fisheries, GFCM's scientists have proposed the strengthening of several regulatory measures for the bottom trawl fishery of the Straights of Sicily: (1) a 25\% reduction in the fishing capacity of trawlers smaller than $18 \mathrm{~m}$; (2) a 45 days fishery closure; (3) the adoption of diamond mesh of $50 \mathrm{~mm}$ (Accadia et al., 2009). In the present study $40 \mathrm{~mm}$ square mesh is substituted for $50 \mathrm{~mm}$ diamond mesh due to its similar selectivity, the fishing closure is extended to 60 days and the tax for biological recovery is terminated. The results of this study suggest that these regulatory measures allow the assigned objectives to be achieved: shrimp and fish biomasses increase and the annual private profit is maintained at a high value from 2013, at $93 \%$ of its mean historic value from 1999 to 2006.

Strengthening the fishing capacity reduction to $50 \%$ further improves the previous results. The shrimp biomass stabilizes at a higher level than during the 1999 - 2006 period. The biomasses of various fish species increase and exceed their 1990 levels by the end of the projected period, with the exception of hake and surmullet, which reached $93 \%$ and $79 \%$ of their starting biomass, respectively. At the end of the projected period, the biomasses of Atlantic horse mackerel, bogue, picarel and spotted flounder exceed their maximum levels observed during the calibration period, while the biomass of the four remaining species reach levels ranging between $70 \%$ and $92 \%$ of their maximum. The spotted flounder biomass, which was very low at the end of calibration period, is twice as high as its maximum recorded during the calibration period by the end of projected period. The private profit and economic rent stabilize from 2013 onwards at levels that are 53\% and 98\% higher respectively, as compared to those from the peak period between 1999 and 2006.

When the final measure included in the European regulations, the complete removal of fuel subsidies, is added, positive values of the annual state revenue are reached, while the annual private profit is only marginally affected. This improves the economic rent and therefore the contribution of the fishery to the society as a whole. Significant reductions in fishing effort are recommended in Mediterranean demersal trawl fisheries catching the hake stock in the straits of Sicily (FAO/GFCM/CGPM/SAC/SCSA, 2013, GFCM/CGPM, 2014). In a demersal 
fishery in the Balearic Sea, bioeconomic modeling showed that a 48-71\% decrease in fishing effort would increase the economic outcomes and improve the health of fish stocks (Merino et al., 2015). Reducing the capacity of the fleet achieved by the permanent withdrawal of boats, will lead to large economical and ecological benefits. In such cases, fishers who exit a particular fishing sector frequently move to an alternative fishing sector. In this manner, when the fleet decreased by 53\% between 1999 and 2007 in French Guiana, the shrimp vessels' crews turned towards small scale fisheries which use more selective fishing methods than the bottom trawling. The saving incurred by the state following the removal of subsidies would allow vessel owners whose boats are demolished to be compensated, and similarly, provide financial support to allow crews to transfer to the artisanal fishery sector with improved selectivity.

However, this model provides a rough representation of the reality and could be refined further. Due to the lack of information, taxes on benefits are not taken into account. A portion of the landed fish catch is not considered. The model does not take into account catch and effort of other fishing sectors on the eight fish species that are also caught in gillnets of the small-scale fishery or by midwater trawls. The small-scale fishery results in fishing mortality of large individuals, but at low rates, while the trawl fishery results in higher fishing mortality rates, but on smaller individuals (Gharbi et al., 2004, Gharbi and Cherif, 2005, Ben Meriem et al., 2012). The model assumes that discard rates of both shrimp and fish are insignificant, according to the low discard rates observed in Mediterranean shrimp trawl fisheries. Among the fleet of Mazara Del Vallo, shrimp discards are estimated at $0,5 \%$ of the total shrimp catch, and the discard of bycatch species ranges between $38 \%$ and $54 \%$ of the total bycatch (Castriota et al., 2001). In this fleet, high values of shrimp discards have been reported, reaching $27 \%$ (Vitale et al., 2006). More generally, in Mediterranean deep water bottom trawl fisheries, discards typically represent $56 \%$ to $77 \%$ of the total catch (Sacchi, 2008b). In 20 trawls in Northern Tunisia in 2000 total discards represented $22 \%$ of the total catch, while shrimp and fish landing were $39 \%$ each. In depths greater than $100 \mathrm{~m}$ there proportions were 13\%,57\% and 33\% respectively (Balti, 2000). Predator-prey relationships are also not taken into account although the eight fish species considered in this study are all predators of various life stages of shrimp (larvae, juveniles and adults), and are also inter-linked among themselves through predator-prey relationships (Golani and Galil, 1991, Papaconstantinou and Stergiou, 1995, Labropoulou et al., 1997, Labropoulou and Papadopoulou-Smith, 1999, Cartes et al., 2002, Machias and Labropoulou, 2002, Stergiou and Karpouzi, 2002, Carpentieri et al., 2005, Colloca et al., 2010). In this study, the stock-recruitment relationship was not embedded because of uncertainty around recruitment, owing to the regeneration of the data set. Nevertheless, it is now commonly acknowledged that stock-recruitment relationships exist in shrimp fisheries (Wang and Die, 1996, Ye, 2000, Wang and Liu, 2006). Finally, this model assumes that the stock of deep-water rose shrimps exploited by the trawl fishery of the northern Tunisian coast is not shared with other fleets, whereas in reality it has been considered a stock shared with Italian and Maltese fisheries since 2010 (Ben Meriem et al., 2010, Ben Meriem et al., 2011). Nevertheless, most of the fish stocks exploited by this Tunisian fishery are considered unshared. The model presented in this study must be extended to whole the Strait of Sicily and incorporate more species, and more fleets including coastal artisanal sectors.

Despite the shortcomings highlighted above, this study suggests that the ecological and economic state of the shrimp fishery of the northern Tunisian coast could be improved using a range of strengthened measures. The predefined objective of improving the ecosystem would be achieved; the biomasses of shrimp and fish would increase beyond their initial level with fishing effort five times lower than those of 2008. These results are 
consistent with global studies (Sumaila et al., 2012). However the negative impacts of bottom trawling on demersal and benthic communities and on the sea bed due to mechanical disturbance would not be suppressed but only reduced. The objective of improving economic outcomes would also be achieved as both the private profit and the societal rent would be significantly strengthened. These ecological and economic improvements would allow the Northern demersal fishery to expand the aspects that promote more selective fishing practices. Through this study, bioeconomic modeling appears to be an essential tool in the fishery management process, complementary to the existing biological diagnostics tools. Specifically, the study of multiple scenarios allows optimal trade-offs in regulatory measures to be identified, producing economic and ecological viability, and taking into account the majority of the species affected by the fishery and ideally the majority of the fishing sectors. Furthermore, bioeconomic models can also be used as a monitoring tool to allow the adjustment of regulatory measures when necessary.

This study has led to several questions, among which the reasons for the lack of implementation of the resolutions and the recommendations of the GFCM by the majority of its members, considering the potential benefits they could provide, is crucial. The resistance to these proposed measures underlines the fear that states show towards reform in fisheries sectors due to the social risks of economic depletion. Furthermore, these sectors typically exhibit a considerable lack of socio-economic diagnostics linked to biological assessments further perpetuating the resistance to change. Bio economic modeling must be encouraged and developed within the GFCM area, and whose results should be integrated with biological assessments recommendations.

\section{Acknowledgements}

The authors would like to thank the anonymous representatives of Tunisian DGPA for providing authorization to access their data base, as well as the stakeholders from fishery, encountered during 2011 and 2012, for sharing their invaluable knowledge, particularly with economic and exploitation data which were essential for completing this study.

This study was supported by EU FP7 CREAM project (Coordinating research in support to application of EAF (Ecosystem Approach to Fisheries) and management advice in the Mediterranean and Black Seas), Grant agreement $n^{\circ} 265648$. The Project’s Working Package 6 leader, Philippe Cury, and the deputy leader, Christian Chaboud, who encouraged this study, are also gratefully acknowledged.

The authors thank two anonymous reviewers for their great help improving the manuscript and Dr John Filmalter for final language revision.

\section{References}

Abdesselem, F., M., M.T., Jarboui, O. (1998) La pêche au chalut benthique sur les côtes nord de la Tunisie. Cahiers Options Méditerranéennes CIHEAM-IAMZ 35, 301-308.

Abelló, P., Abella, A., Adamidou, A., Jukic-Peladic, S., Maiorano, P., Spedicato, M.T. (2002) Geographical patterns in abundance and population structure of Nephrops norvegicus and Parapenaeus longirostris (Crustacea: Decapoda) along the European Mediterranean coasts. Scientia Marina 66, 125-141.

Accadia, P., Gambino, M., Sabatella, R., Spagnolo, M. (2009) An Adaptative Management Plan for the Italian Fisheries. In: XIXth Conference of the European Association of Fisheries Economists (EAFE). Past, present and future of property rights (IQ, ITQ and TURFS) in European fisheries. Malta, 6-8 July 2009, p. $17 \mathrm{pp}$. 
Alverson, D.L., Freeberg, M.H., Murawski, S.A., Pope, J.G. (1994) A global assessment of fisheries bycatch and discards. FAO Fisheries Technical Paper 339, 1-233.

Anonymous (1962) Loi n $62-35$ du 16 octobre 1962, modifiant le décret du 26 juillet 1951, portant refonte de la législation de la police de la pêche maritime et délimiation des eaux territoriales de la République Tunisienne. journal Officiel de la République Tunisienne 53, p 1224.

Anonymous (1963a) Loi No $63-50$ du 30 décembre 1963 portant ratification de l'accord relatif à la pratique de la pêche par les pêcheurs italiens dans les eaux tunisiennes, conclu entre le Gouvernement de la République Tunisienne et le Gouvernement de la République Italienne. journal Officiel de la République Tunisienne 60, 1870-1872.

Anonymous (1963b) Loi № 63-49 du 30 decembre 1963 portant modification du décret du 26 juillet 1951 portant refonte de la législation de la police de la pâche. journal Officiel de la République Tunisienne 60, p 1870.

Anonymous (1972a) Loi № 72-16 du 10 mars 1972, portant ratification de l'Accord signé à Tunis le 20 août 1971, entre le gouvernement de la République Tunisienne et le Gouvernement de la République Italienne relatif à la délimitation du plateau Continental entre les deux pays. journal Officiel de la République Tunisienne 11, p 312.

Anonymous (1972b) Loi № $72-17$ du 10 mars 1972, portant ratification de l'Accord conclu à Tunis le 20 août 1971, entre le Gouvernement de la République Tunisienne et le Gouvernement de la République Italienne, relatif à la pratique de la pêche dans les eaux tunisiennes par des nationaux italiens. journal Officiel de la République Tunisienne 11, p 312.

Anonymous (1976) Loi № 76-96 du 15 novembre 1976, portant ratification de l'Accord signé à Rome le 19 juin 1976, entre le gouvernement de la République Tunisienne et le gouvernement de la République Italienne relatif à la pêche dans les eaux tunisiennes par des nationaux italiens. journal Officiel de la République Tunisienne 70, p 2775.

Anonymous (1994) Loi n $94-13$ du 31 janvier 1994, relative à l'exercice de la pêche. journal Officiel de la République Tunisienne 11, 227-230.

Anonymous (2005) Loi $n^{\circ}$ 2005-50 du 27 juin 2005, relative à la zone économique exclusive au large des côtes tunisiennes. journal Officiel de la République Tunisienne 51, 1427-1428.

Anonymous (2007) Vensim ${ }^{\circledR}$ - Ventana ${ }^{\circledR}$ Simulation Environment, Version 8 - User's guide Vol., Ventana Systems, Inc., Harvard, MA, USA.

Anonymous (2009) Loi n 2009-17 du 16 mars 2009 relative au régime du repos biologique dans le secteur de la pêche et son financement. journal Officiel de la République Tunisienne 22, 785-786.

Ardizzone, G.D., Gravina, M.F., Belluscio, A., Schintu, P. (1990) Depth-Size Distribution Pattern of Parapenaeus longirostris (Lucas, 1846) (Decapoda) in the Central Mediterranean Sea. Journal of Crustacean Biology 10, $139-147$.

Arreguin-Sanchez, F., Zetina-Rejón, M., Ramírez-Rodríguez, M. (2008) Exploring ecosystem-based harvesting strategies to recover the collapsed pink shrimp (Farfantepenaeus duorarum) fishery in the southern Gulf of Mexico. Ecological Modelling 214, 83-94.

Balti, M. (2000) La pêche hauturière dans le nord de la Tunisie. Mémoire de fin d'étude, Institut National Agronomique de Tunis, 19 pages.

Bazairi, H., Ben Haj, S., Boero, F., et al. (2010) The Mediterranean Sea Biodiversit: state of the ecosystems, pressures, impacts and future priorities. UNEP-MAP, RAC/SPA, $100 \mathrm{pp}$.

Ben Meriem, S. (1993) Taille de première maturité et période de ponte de Penaeus kerathurus dans le Golfe de Gabès, Tunisie (Decapoda, Penaeoidea). Crustaceana 65, 82-96.

Ben Meriem, S., Fehri-Bedoui, R., Gharbi, H. (2001) Size at maturity and ovigerous period of the pink shrimp Parapenaeus longirostris (Lucas, 1846) in Tunisia. Crustaceana 74, 39-48.

Ben Meriem, S., Fiorentino, F., Arneri, A., et al. (2011) SAC GFCM Sub-Committee on Stock Assessment Parapenaeus longirostris, GSA 12, 13, 14, 15 and 16. SAC GFCM Sub-Committee on Stock Assessment Forms, $44 \mathrm{pp}$.

Ben Meriem, S., Fiorentino, F., Arneri, E., et al. (2012) Stock Assessment Form. Demersal species 2012 - Hake. $15 \mathrm{pp}$.

Ben Meriem, S., Fiorentino, F., Gancitano, V., et al. (2010) Stock assessment forms Parapenaeus longirostris GSA 12-15-16 (MEDSUDMED) Stock assessment forms, 52 pp.

Ben Meriem, S., Missaoui, H., Zarrad, R., Bedoui, R., Gharbi, H. (1998) Approche globale de l'évaluation des ressources de la chevrette (Parapenaeus longirostris) de la région septentrionale de la Tunisie. Bulletin INSTM 25, 5-15. 
Ben Rais Lasram, F., Guilhaumon, F., Albouy, C., Somot, S., Thuiller, W., Mouillot, D. (2010) The Mediterranean Sea as a 'cul-de-sac' for endemic fishes facing climate change. Global Change Biology 16, 3233-3245.

Béné, C. (1997) Dynamique et adaptation d'un système- pêche face aux perturbations de son environnement. Analyses et modélisations dynamiques du couplage écologie - économie ; le cas de la pêcherie crevettière guyanaise. Thèse de doctorat Sciences biologiques fondamentales et appliquées Université de Paris 6 Pierre et Marie Curie, 384 p. pages.

Blomo, V.J., Nichols, J.P., Griffin, W.L., Grant, W.E. (1982) Dynamic Modeling of the Eastern Gulf of Mexico Shrimp Fishery American Agricultural Economics Association 64, 475-482.

Caddy, J.F. (1993) Some future perspectives for assessment and management of Mediterranean fisheries. Scientia Marina 57, 121-130.

Carpentieri, P., Colloca, F., Cardinale, M., Belluscio, A., Ardizzone, G.D. (2005) Feeding habits of European hake (Merluccius merluccius) in the central Mediterranean Sea. Fishery Bulletin 103, 411-416.

Cartes, J.E., Abello, P., Lloris, D., et al. (2002) Feeding guilds of western Mediterranean demersal fish and crustaceans: an analysis based in a spring survey. Scientia Marina 66, 209-220.

Castriota, L., Campagnuolo, S., Andaloro, F. (2001) Shrimp Trawl Fishery By-catch in the Straits of Sicily (Central Mediterranean Sea). In: NAFO Scientific Council Meeting - September 2001. Vol. Serial No. N4501. pp. 1-9.

Chaboud, c. (2000) Un modèle de simulation bio-économique d'une pêcherie crevettière tropicale. Perspective d'application à la pêcherie malgache. In: Aménagement de la pêche crevettière à Madagascar. MPRH FAO, Antananarivo, Madagascar, 12-14 décembre 2000, pp. 272-297.

Chaboud, C. (2008) Modèlisation bioéconomique de la pêcherie crevettière malgache. In: Les crevettes côtières de Madagascar. Biologie, exploitation, gestion. (Ed. I. Editions), Marseille, pp. 261-310.

Chaboud, C., Thébaud, O. (2009) Bioeconomic model of the dynamics of fisheries facing global economic and environment changes: the French Guyana shrimp fishery. In: 18th World IMACS Congress and MODSIM09 International Congress on Modelling and Simulation, Cairns, Australia,13-17 July, 2009. (Eds. R.S. Anderssen, R.D. Braddock, L.T.H. Newham), Modelling and Simulation Society of Australia and New Zealand and International Association for Mathematics and Computers in Simulation, Cairns, Australia, pp. 2079-2086.

Chaboud, C., Vendeville, P. (2011) Evaluation of selectivity and bycatch mitigation measures using bioeconomic modelling. The cases of Madagascar and French Guiana shrimp fisheries. Aquatic Living Resources 24, 137-148.

Chaboud, C., Vendeville, P., Blanchard, F., Viera, A. (2008) Bioeconomic modelling as an integrative tool to assess the dynamics of fisheries facing global economic and environment changes. The example of the French Guyana shrimp fishery model. In: GLOBEC-EUROCEANS-FAO Symposium "Coping with global change in marine social-ecological systems". Rome, Italy, 8-10 July 2008, p. 21.

Chaouachi, B., Ben Hassine, O.K. (1998) Données sur la pêche des crevettes profondes Parapenaeus Iongirostris (Lucas, 1846) en Tunisie CIHEAM- Cahiers Options Méditerranéennes 35, 201-213.

Clark, C.W., Kirkwood, G.P. (1979) Bioeconomic model of the Gulf of Carpentaria prawn fishery. J. Fish. Res. Board Can. 36, 1304-1312. [In English].

Colloca, F., Carpentieri, P., Balestri, E., Ardizzone, G. (2010) Food resource partitioning in a Mediterranean demersal fish assemblage: the effect of body size and niche width. Marine Biology 157, 565-574.

Crosnier, A., De Bondy, E. (1967) Les crevettes commercialisables de la côte ouest de l'Afrique inter-tropicale. In: Initiations- Documentations techniques. Vol. 7. (Ed. ORSTOM), p. 60.

Darby, C. (2003) Appendix 1 : The Lowestoft Stock Assessment Suite - Tutorial 4, Extended Survivors Analysis (XSA). NAFO Scientific Council Studies 36, 79-102.

Darby, C.D., Flatman, S. (1994) Virtual Population Analysis: Version 3.1 (Windows/DOS) user guide. MAAF Information Technology Series, $85 \mathrm{pp}$.

Dintheer, C., Gilly, B., Le gall, J.-Y., Lemoine, M., Rosé, J. (1991) La recherche et la gestion de la pêcherie de crevettes Pénéides en guyane Française de 1958 à 1988 : trente année de surf. In: La Recherche face à la Pêche Artisanale. Vol. II. (Eds. J.-R. Durand, J. Lemoalle, J. Weber), ORSTOM, Montpellier, France, 3-7 juillet 1989, pp. 859-870.

Durrieu de Madron, X., Guieu, C., Sempere, R., et al. (2011) Marine ecosystems' responses to climatic and anthropogenic forcings in the Mediterranean. Progress In Oceanography 91, 97-166.

Ebert, S., Metschies, G.P., Schmid, D., Wagner, A. (2009) International fuel prices 2009, 6th Edition - More than 170 Countries. 109 pp. 
EC (2006) Council Regulation (EC) № 1967/2006 of 21 December 2006 concerning management measures for the sustainable exploitation of fishery resources in the Mediterranean Sea, amending Regulation (EEC) No 2847/93 and repealing Regulation (EC) № 1626/94. Official Journal of the European Union L 409, 11-84.

Ehrhardt, N.M., Legault, C.M. (1999) Pink Shrimp, Farfantepenaeus duorarum, Recruitment Variability as an Indicator of Florida Bay Dynamics. Estuaries 22, 471-483.

Elouamari, N., Pérez Gil, J.L., Benchoucha, S., et al. (2011) Advances in the joint assessment of Parapenaeus longirostris stock for Algeria, Morocco and Spain (GSAs 01, 02, 03 and 04 of the GFCM). Paper presented at the Working Group on Stock Assessment of Demersal Species (SCSA-SAC, GFCM), (Chania, Crete. Greece, 24-29 October 2011). 12 pp.

FAO (2012a) Fisheries and Aquaculture Department, Statistics and Information Service FishStatJ: Universal software for fishery statistical time series. Copyright 2011.

FAO (2012b) The State of World Fisheries and Aquaculture 2012. 209 pp.

FAO (2014) The State of World Fisheries and Aquaculture 2014. 223 p.

FAO/GFCM (2009) General Fisheries Commission for the Mediterranean. Report of the thirty-third session. GFCM report, $126 \mathrm{pp}$.

FAO/GFCM/CGPM (2002) Report of the twenty-seventh session. Rome, 19-22 November 2002. GFCM Report, $36 \mathrm{pp}$.

FAO/GFCM/CGPM (2005) Report of the twenty-ninth session. Rome, 21-25 February 2005. GFCM Report, 50 $\mathrm{pp}$.

FAO/GFCM/CGPM (2007) Report of the thirty-first session. Rome, 9-12 January 2007. GFCM Report, 80 pp.

FAO/GFCM/CGPM (2010) Report of the thirty-fourth session. Athens, Greece, 12-17 April 2010. GFCM Report, $98 \mathrm{pp}$.

FAO/GFCM/CGPM (2012) Report of the Fourteenth Session of the Scientific Advisory Committee. Sofia, Bulgaria, 20-24 February 2012/Rapport de la quatorzième session du Comité Scientifique Consultatif. Sofia, Bulgarie, 20-24 février 2012. FAO Fisheries and Aquaculture Report/FAO Rapport sur les pêches et l'aquaculture, $200 \mathrm{pp}$.

FAO/GFCM/CGPM/SAC/SCSA (2013) Report of the working group on stock assessment of demersal species. Split, Croatia 5-9 november 2012.81 p.

FAO/GFCM/CGPM/SAC/SCSA (2014) Report of the Working Group on Stock Assessment of Demersal Species (WGSAD - Rome, Italy, 24-27 November 2014. GFCM/CGPM Report, 58 pp.

FAO/GFCM/CGPM/SAC/SCSA (2015) Report of the Working Group on Stock Assessment of Demersal Species (WGSAD - Rome, Italy, 23-28 November 2015. GFCM/CGPM Report, 60 pp.

Fiorentino, F., Ben Meriem, S., Bahri, T., et al. (2008) Synthesis of information on some target species in the MedSudMed Project area (central Mediterranean). MedSudMed Technical Documents 15, $67 \mathrm{p}$.

Garcia, S., Le Reste, L. (1981) Cycles vitaux, dynamique, exploitation et aménagement des stocks de crevettes penaeides côtières. FAO Document technique sur les pêches 203, 210 p.

GFCM/CGPM (2005) 2005 - Recommendations on Mediterranean fisheries management (no Resolutions). Recommendations and Resolutions Reports, $12 \mathrm{pp}$.

GFCM/CGPM (2007) 2007 - GFCM Recommendations and Resolutions on Mediterranean fisheries management. Recommendations and Resolutions Reports, $29 \mathrm{pp}$.

GFCM/CGPM (2014) Report of the Working Group on Stock Assessment of Demersal Species (WGSAD). Bar, Montenegro, 28 January - 1 February 2014. 41.

Gharbi, H., Ben Meriem, S., Bedoui, R., El Abed, A. (2004) Les pêcheries tunisiennes du rouget de vase (Mullus barbatus Linnaeus, 1758) : évaluation des stocks et aménagement des pêcheries - The Tunisian fisheries of red mullet (Mullus barbatus Linnaeus, 1758): stock assessment and fisheries management. Marine Life 14, 49-57.

Gharbi, H., Cherif, M. (2005) Actualisation de l'évaluation des stocks du rouget de roche (Mullus surmuletus) en Tunisie : mortalités et analyse des rendements par recrue. In: Séminaire INSTM- CGPM SCSA - 2005. Salambô, Tunisie, p. 26.

Gillett, R. (2008) Global study of shrimp fisheries. FAO Document technique sur les pêches 475, 331p.

Gilly, B., Cochet, Y. (1987) Analyse bio-économique de l'exploitation des crevettes en Guyane française. Document de travail SDA, $99 \mathrm{pp}$.

Golani, D., Galil, B. (1991) Trophic relationships of colonizing and indigenous goatfishes (Mullidae) in the eastern Mediterranean with special emphasis on decapod crustaceans. Hydrobiologia 218, 27-33. 
Grant, W.E., Griffin, W.L. (1979) A Bioeconomic Model of the Gulf of Mexico Shrimp Fishery. Transactions of the American Fisheries Society 108, 1-13.

Grant, W.E., Isakson, K.G., Griffin, W.L. (1981) A general bioeconomic simulation model for annual-crop marine fisheries. Ecological Modelling 13, 195-219.

Guéguen, F. (2000) Distribution et abondance des crustacés décapodes du talus continental (200-900 m) de Guyane française. Crustaceana 73, 685-703.

Guijarro, B., Massutí, E. (2006) Selectivity of diamond- and square-mesh codends in the deepwater crustacean trawl fishery off the Balearic Islands (western Mediterranean). ICES Journal of Marine Science: Journal du Conseil 63, 52-67.

Güngör, H., Zengi, M., Güngör, G. (2007) Socio-Economic Structure of the Deep Water Pink Shrimp Fisheries i, the Maramara Sea. Journal of Tekirdag Agricultural Faculty 4, 261-269.

Halouani, G., Ben Rais Lasram , F., Khalfallah, M., Zeller, D., Pauly, D. (2015) Reconstruction of Marine Fisheries catches for Tunisia (1950-2010). Vol. 2015-95. Working paper (Ed. U.o.B.C. Fisheries Centre), Vancouver, Canada, p. 11 p.

Holthuis, L.B. (1980) Shrimps and prawns of the world. An annotated Catalogue of Species of Interest to Fisheries. FAO Fisheries Synopsis 125, 1-271.

INST (2010) Annuaire Statistique de la Tunisie 2005-2009. 349 pp.

INST (2011) Annuaire Statistique de la Tunisie 2006-2010. No. 0066-3689, 352 pp.

INST (2012) Statistiques du commerce extérieur 2011. N 42.428 pp.

Jarboui, O., Zamouri, n., Ben Hadj Hamida, N., Hechmi, M. (2005) Etude des rejets du chalutage benthique sur les côtes tunisiennes. document COPEMED, $25 \mathrm{p}$.

Kelleher, K. (2005) Discards in the world's marine fisheries. An update. FAO Fisheries Technical Paper 470, 1131.

Kelleher, K. (2008) Les rejets des pêcheries maritimes mondiales. Une mise à jour. FAO Document technique sur les pêches 470, 1-147.

Kirkwood, G.P. (1984) Modelling of the Gulf of Carpentaria prawn fisheries. In: Penaeid shrimps: their biology and management. (Eds. J.A. Gulland, B.J. Rothschild), Fishing News Books, Oxford, pp. 211-219.

Labropoulou, M., Machias, A., Tsimenides, N., Eleftheriou, A. (1997) Feeding habits and ontogenetic diet shift of the striped red mullet, Mullus surmuletus Linnaeus, 1758. Fisheries Research 31, 257-267.

Labropoulou, M., Papadopoulou-Smith, K.N. (1999) Foraging Behaviour Patterns of Four Sympatric Demersal Fishes. Estuarine, Coastal and Shelf Science 49, Supplement 1, 99-108.

Lam, V.W.Y., Sumaila, U.R., Dyck, A., Pauly, D., Watson, R. (2011) Construction and first applications of a global cost of fishing database. ICES Journal of Marine Science: Journal du Conseil 68, 1996-2004.

Leanza, U. (1994) Le régime juridique de la mer méditerranée. In: Collected Courses of the Hague Academy of International Law : 1992. Martinus Nijhoff, pp. 127-460.

Levi, D., Andreoli, M.G., Giusto, R.M. (1995) First assessment of the rose shrimp, Parapenaeus longirostris (Lucas, 1846) in the central Mediterranean. Fisheries Research 21, 375-393.

Lleonart, J., Maynou, F., Recasens, L., Franquesa, R. (2003) A bioeconomic model for Mediterranean fisheries, the hake off Catalonia (western Mediterranean) as a case study. Scientia Marina 67, 337-351.

M'Rabet, R. (2003) La mise au point des engins de pêche sélectifs est une contribution à une gestion rationnelle et durables des pêcheries en Tunisie. In: Projet FAO/COPEMED, Forum international sur la pêche en Méditerranée Occidentale - Madrid, 23-25 Juillet 2003, p. 14.

Machias, A., Labropoulou, M. (2002) Intra-specific Variation in Resource Use by Red Mullet, Mullus barbatus. Estuarine, Coastal and Shelf Science 55, 565-578.

Machias, A., Maiorano, P., Vassilopoulou, V., Papaconstantinou, C., Tursi, A., Tsimenides, N. (2004) Sizes of discarded commercial species in the eastern-central Mediterranean Sea. Fisheries Research 66, 213222.

Maynou, F., Morales-Nin, B., Cabanellas-Reboredo, M., Palmer, M., García, E., Grau, A.M. (2013) Small-scale fishery in the Balearic Islands (W Mediterranean): A socio-economic approach. Fisheries Research 139, 11-17.

Mc Guire, T.R. (1991) Science and the Destruction of a Shrimp Fleet. Maritime Security, Maritime Systems and Maritime Technology review 41, 32-55.

Merino, G., Karlou-Riga, C., Anastopoulou, J., Maynou, F., Lleonart, J. (2007a) Bioeconomic simulation analysis of hake and red mullet fishery in the Gulf of Saronikos (Greece). Scientia Marina 71, 525-535. 
Merino, G., Maynou, F., Gardcia-Olivares, A. (2007b) Effort dynamics in a fisheries bioeconomic model: A vessel level approach through Game Theory. Scientia Marina 71, 537-550.

Merino, G., Quetglas, A., Maynou, F., et al. (2015) Improving the performance of a Mediterranean demersal fishery toward economic objectives beyond MSY. Fisheries Research 161, 131-144.

Papaconstantinou, C., Stergiou, K.I. (1995) Biology and fisheries of eastern Mediterranean hake (M. merluccius). In: Hake: Biology, fisheries and markets. (Eds. J. Alhelt, T.J. Pitcher), Chapman \& Hall, London, pp. 149-180.

Planchot, M., Daures, F. (2008) Le secteur français des pêches maritimes face à l'augmentation du prix du gasoil. Note de synthèse. $20 \mathrm{p}$.

Ragonese, S., Andreoli, M.G., Bono, G., Giusto, G.B., Rizzo, P., Sinacori, G. (2004) Overview of the available biological information on demersal resources of the Strait of Sicily MedSudMed Technical Documents 2, 75-82.

Ragonese, S., Bianchini, M.L. (2006) Trawl selectivity trials on the deep-water rose shrimp (Parapenaeus longirostris) in Sicilian waters. Hydrobiologia 557, 113-119.

Ramirez-Rodriguez, M., Arreguin-Sanchez, F. (2003) Spawning stock-recruitment relationships of pink shrimp Farfantepenaeus duorarum in the southern Gulf of Mexico. Bulletin of Marine Science 72, 123-133.

Ramirez Rodriguez, M., Arreguin Sanchez, F., Lluch Belda, D. (2006) Impact of surface temperature and salinity on the recruiting of the pink shrimp Farfantepenaeus duorarum (Decapoda: Penaeidae), in Sonda de Campeche, Gulf of Mexico. Revista De Biologia Tropical 54, 1241-1245. [In Spanish].

Russo, T., Parisi, A., Garofalo, G., Gristina, M., Cataudella, S., Fiorentino, F. (2014) SMART: A Spatially Explicit Bio-Economic Model for Assessing and Managing Demersal Fisheries, with an Application to Italian Trawlers in the Strait of Sicily. PLOS ONE 9, e86222.

Sacchi, J. (2008a) Impact des techniques de pêche sur l'environnement en Méditerranée. Études et revues. Commission générale des pêches pour la Méditerranée. 84, 62 pp.

Sacchi, J. (2008b) The use of trawling nets in the Mediterranean. Problems and selectivity options In: The Mediterranean fisheries sector. A reference publication for the VII meeting of Ministers of agriculture and fisheries of CIHEAM member countries (Zaragoza, Spain, 4 february 2008). Options Méditerranéennes: série B. Etudes et Recherches (Ed. Basurco), CIHEAM-IAMZ / FAO / GFCM, Zaragoza, Spain, pp. 8796.

Sánchez, P., Demestre, M., Martin, P. (2004) Characterisation of the discards generated by bottom trawling in the northwestern Mediterranean. Fisheries Research 67, 71-80.

Sartor, P., Sbrana, M., Reale, B., Belcari, P. (2003) Impact of the deep sea trawl fishery on demersal communities of the northern Tyrrhenian Sea (Western Mediterranean). Journal of Northwest Atlantic Fishery Science 31, 275-284.

SAUP (2016) Sea around US Project. Stock status in the waters of GFCM, 1950-2010. In: Sea Around Us Concepts, Design and Data (seaaroundus.org). Vol. 2016. (Eds. D. Pauly, D. Zeller).

Shepherd, J.G. (1999) Extended survivors analysis: An improved method for the analysis of catch-at-age data and abundance indices. ICES Journal of Marine Science: Journal du Conseil 56, 584-591.

Smith, V.L. (1969) On Models of Commercial Fishing. Journal of Political Economy 77, 181-198.

Sobrino, I., Silva, C., Sbrana, M., Kapiris, K. (2005) A review of the biology and fisheries of the deep water rose shrimp, Parapenaeus longirostris, in European Atlantic and Mediterranean waters (Decapoda, Dendrobranchiata, Penaeidae). Crustaceana 78, 1153-1184.

Stergiou, K., Karpouzi, V. (2002) Feeding habits and trophic levels of Mediterranean fish. Reviews in Fish Biology and Fisheries 11, 217-254.

Stergiou, K.I., Machias, A., Somarakis, S., Kapantagakis, A. (2003) Can we define target species in Mediterranean trawl fisheries? Fisheries Research 59, 431-435.

Sumaila, U.R., Cheung, W., Dyck, A., et al. (2012) Benefits of Rebuilding Global Marine Fisheries Outweigh Costs. PLOS ONE 7:e40542, $12 \mathrm{p}$.

Takeda, M., Okutani, T. (1983) Crustaceans and Mollusks trawled off Suriname and French Guiana, Vol., Japan Marine Fishery Resources Research Center (JAMARC), Tokyo, Japan.

Thomson, J.M. (1955) Fluctuation in Australian Prawn Catch. In: 5 th IPFC Symposium - Prawn Symposium. (Ed. IPFC), Indo-Pacific Fisheries Council, Tokyo, pp. 444-447.

Tom, M., Goren, M., Ovadia, M. (1988) The benthic phase of the life cycle of Parapenaeus longirostris (Crustacea, Decapoda, Penaeidae) along the Mediterranean coast of Israel. Hydrobiologia 169, 339352. 
Tsagarakis, K., Palialexis, A., Vassilopoulou, V. (2014) Mediterranean fishery discards: review of the existing knowledge. ICES Journal of Marine Science: Journal du Conseil 71, 1219-1234.

Tudela, S. (2004) Ecosystem effects of fishing in the Mediterranean: an analysis of the major threats of fishing gear and practices to biodiversity and marine habitats. In: Studies and Reviews. Vol. 74. (Ed. GFCM), Rome, p. 44 p.

Ungaro, N., Gramolini, R. (2003) Relationship between environmental parameters and stock distribution: can the bottom temperature affect the Adriatic population of the deep-water rose shrimp? In: GFCM/CGPM, SCSA Working Group on Demersal Spacies, Tangier, Morocco, March (12-14). Vol. Working Document No15. p. 5.

Vendeville, P. (1990) Tropical Shrimp fisheries types of fishing gears used and their selectivity. FAO Technical Paper 261, 75 pp.

Vitale, S., Cannizzaro, L., Bono, G., Beltrano, A.M., Milazzo, A., Norrito, G. (2006) Catch composition of Decapoda crustaceans from trawl fishery catches in the central Mediterranean Sea. Journal of Coastal Research 39, 1798-1800.

Wang, Y.-G., Die, D. (1996) Stock-Recruitment relationships of the tiger prawns (Penaeus esculentus and Penaeus semisulcatus) in the Australian Northern prawn fishery. Marine and freshwater Resources 47, 87-95.

Wang, Y.J., Liu, Q. (2006) Comparison of Akaike information criterion (AIC) and Bayesian information criterion $(B I C)$ in selection of stock-recruitment relationships. Fisheries Research 77, 220-225.

Ye, Y. (2000) Is recruitment related to spawning stock in penaeid shrimp fisheries. ICES Journal of Marine Science 57, 1103-1109.

Ye, Y., Loneragan, N., Die, D., Watson, R., Harch, B. (2005) Bioeconomic modelling and risk assessment of tiger prawn (Penaeus esculentus) stock enhancement in Exmouth Gulf, Australia. Fisheries Research 73, 231-249.

Zengin, M., Akyol, O. (2009) Description of by-catch species from the coastal shrimp beam trawl fishery in Turkey. Journal of Applied Ichthyology 25, 211-214. 


\section{Figures}

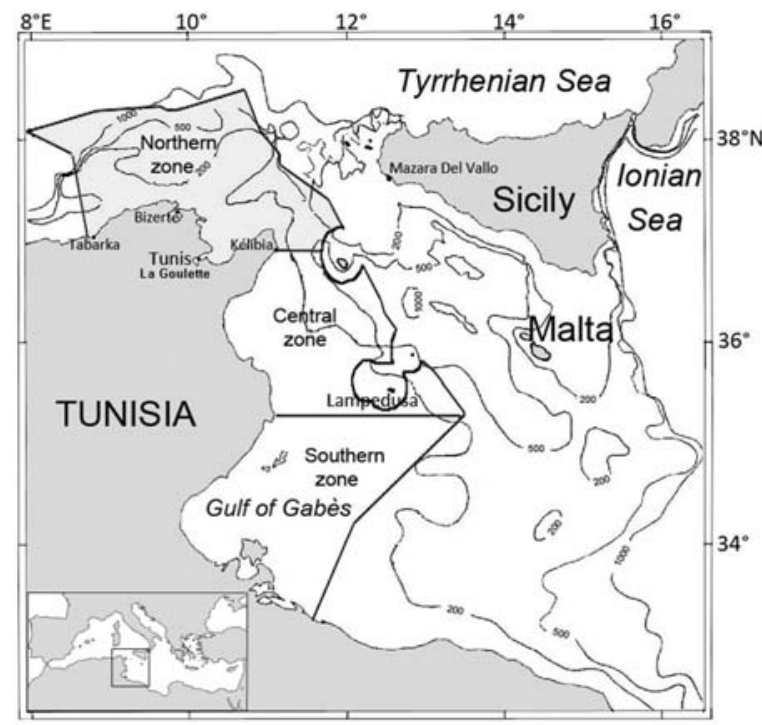

Figure 1: Northern Tunisian bottom trawl fishing area (light greyish), the four shrimp trawler ports and the three administrative fishing zones.

(a)

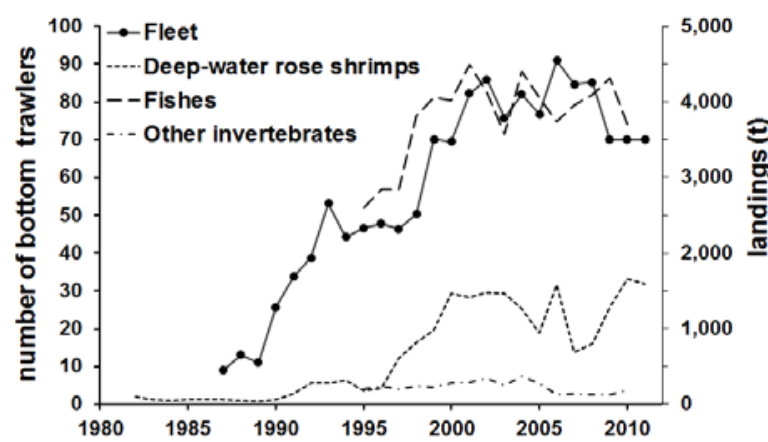

(b)

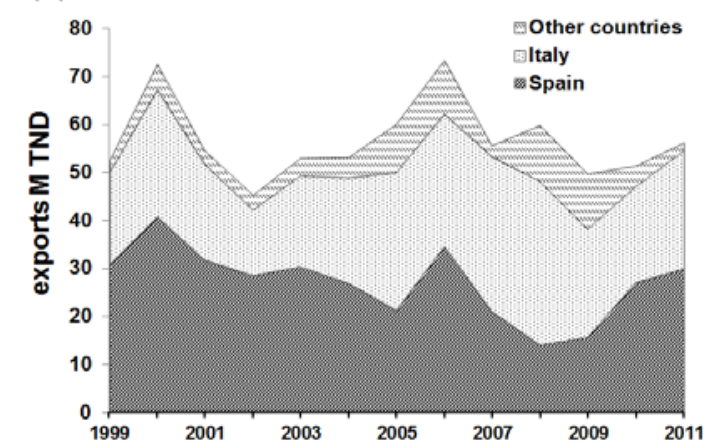

Figure 2: Bottom trawler fishery development in northern Tunisia landing in the four harbors: Kelibia, La Goulette (Tunis), Bizerte and Tabarka (source : DGPMA) (a) and exports of frozen Tunisian shrimps (INST, 2012) (b).
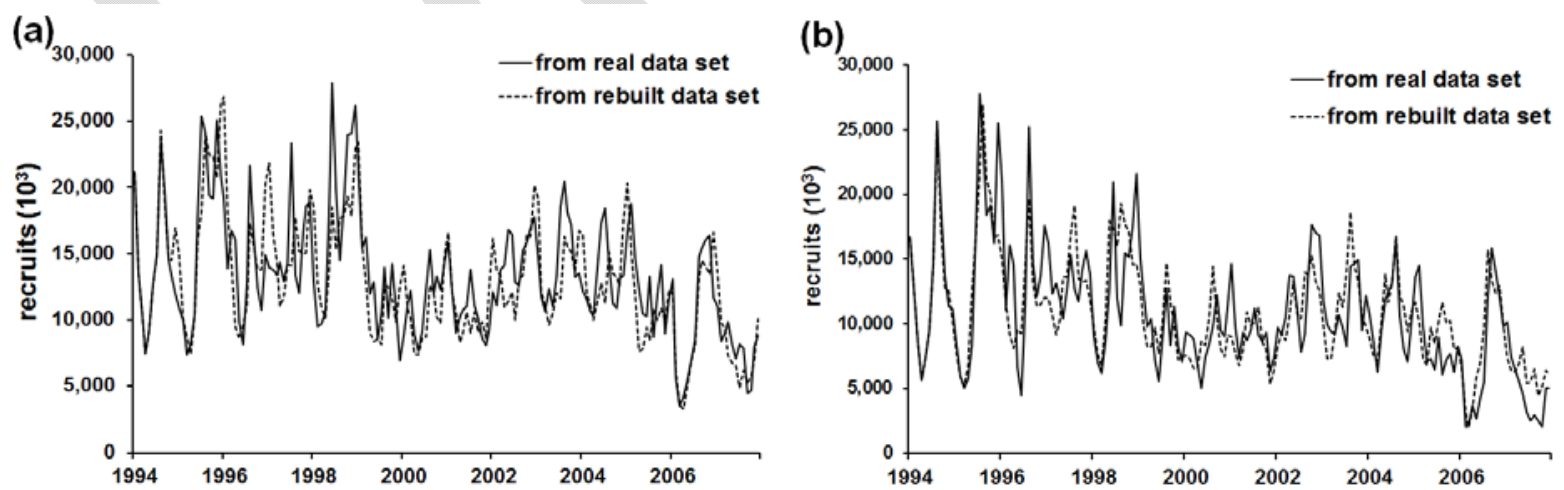

Figure 3: Recruitment in the French Guiana shrimp fishery obtained by VPA-XSA applied to observed monthly length frequencies and to data regenerated following the method described in this paper: females (a) and males (b). 
(a)

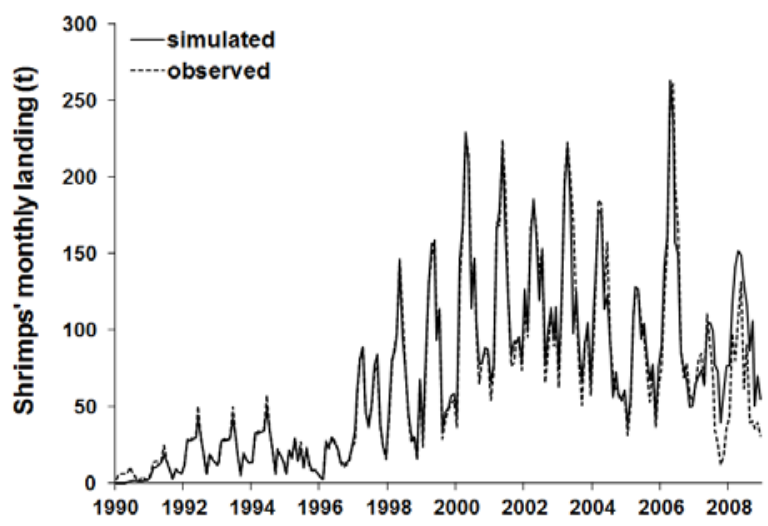

(b)

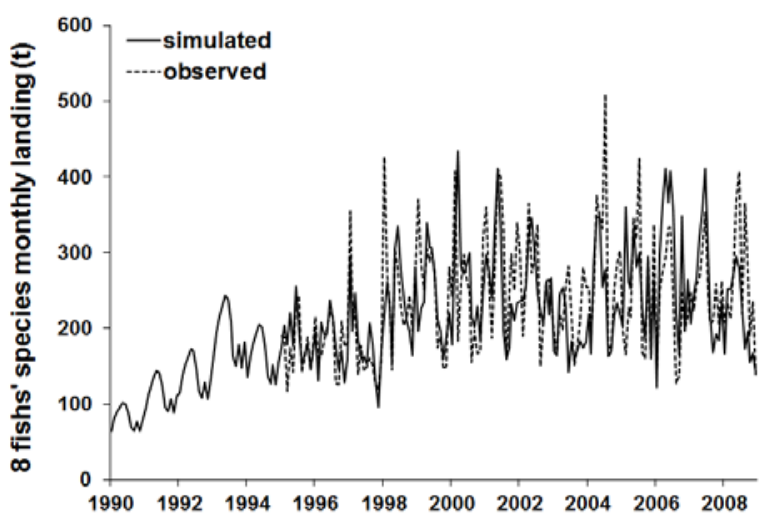

Figure 4: Simulated and observed shrimp landings per month (a) and landing total of all eight species of fishes (b).

(a)

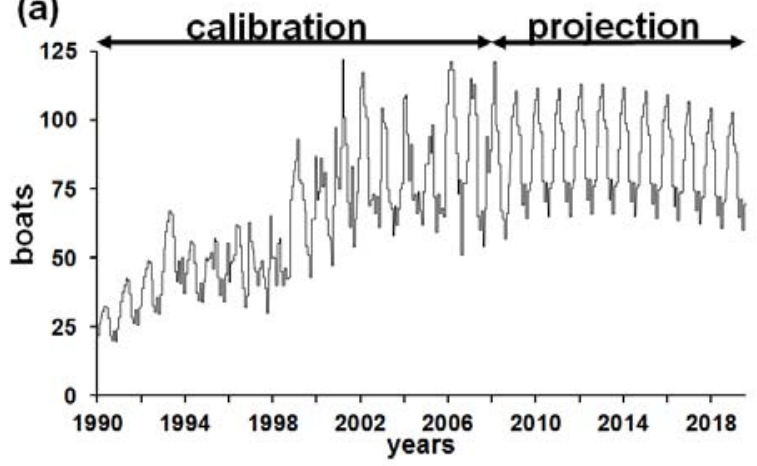

(c)

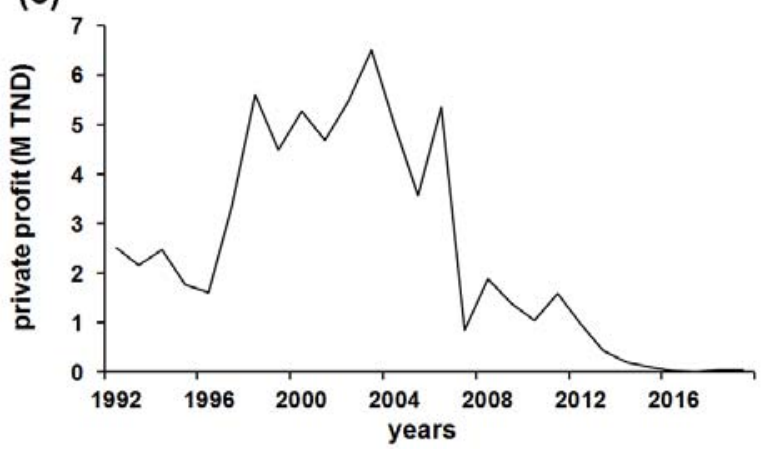

(e)

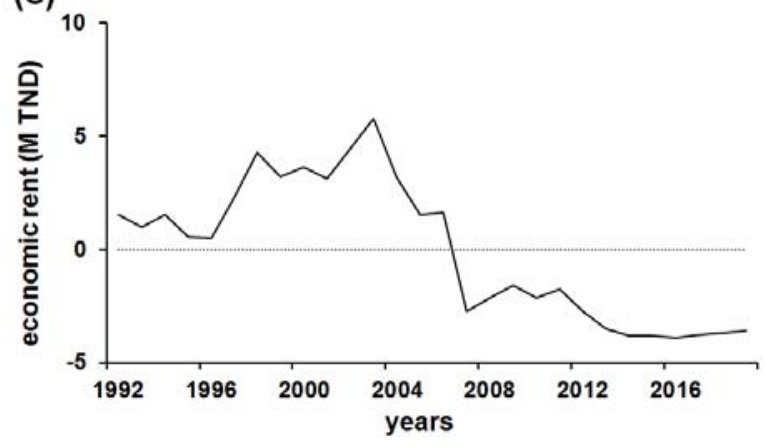

(b)

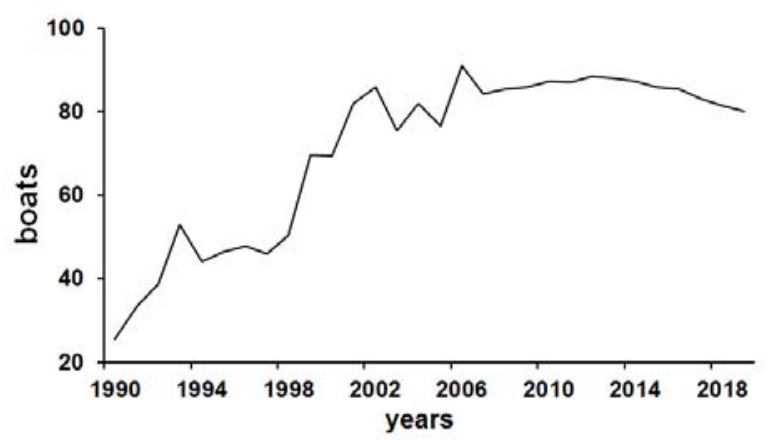

(d)

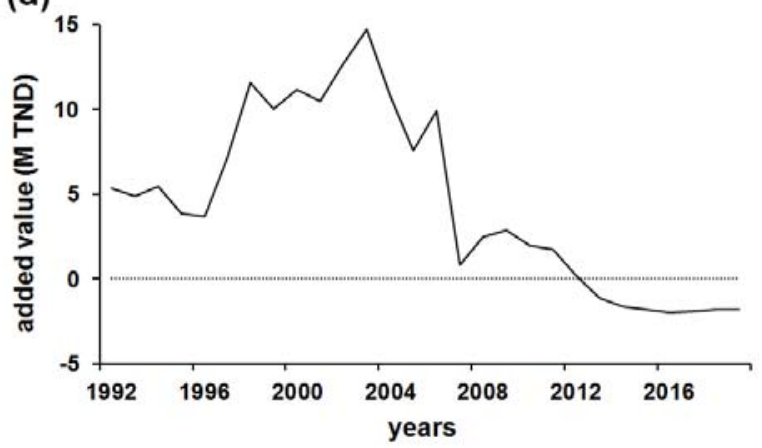

(f)

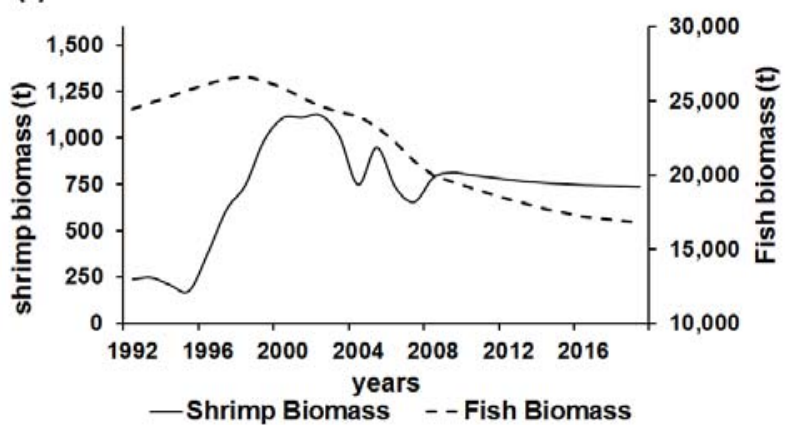

Figure 5: Main indicators in reference scenario $\mathrm{H} 0$ : daily (a) and annual mean number (b) of active trawlers; annual cumulative private profit (c), net added value (d) annual economic rent (e) and annual mean shrimp and fish biomasses (f). 
(a)

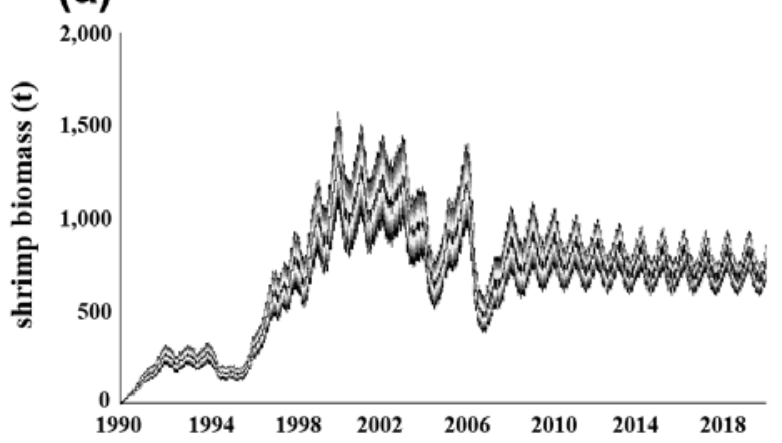

(c)

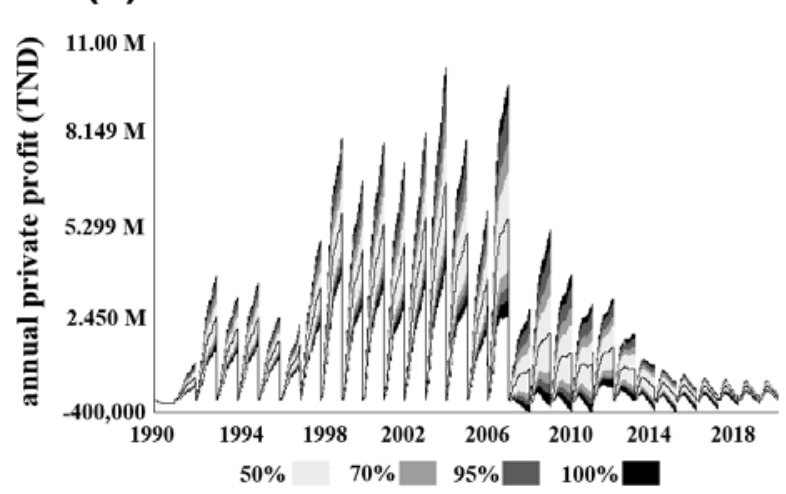

(b)

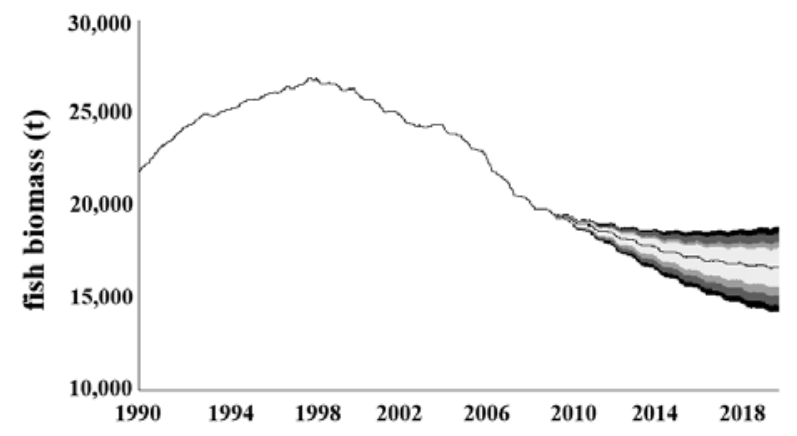

(d)

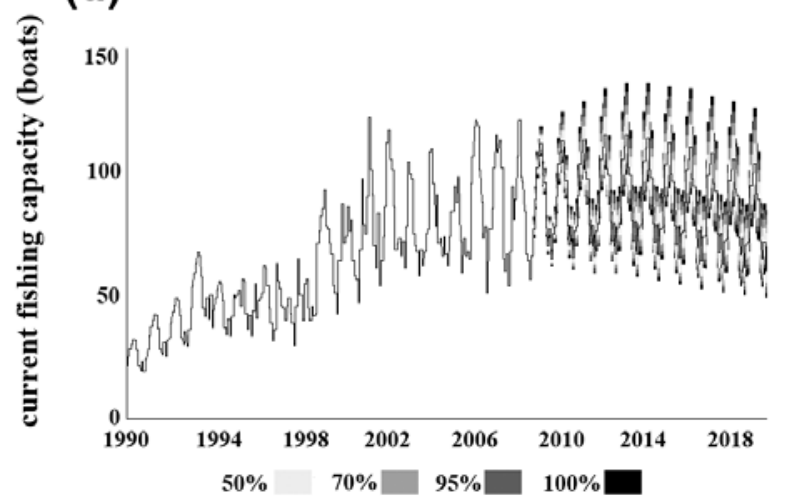

Figure 6: Model sensitivity to parameters $\mathrm{M}$ and $\mathrm{K}$ together on the shrimp biomass (a), the fish biomass (b) the annual cumulative private profit (c) and the current fishing capacity (d). 
(a)

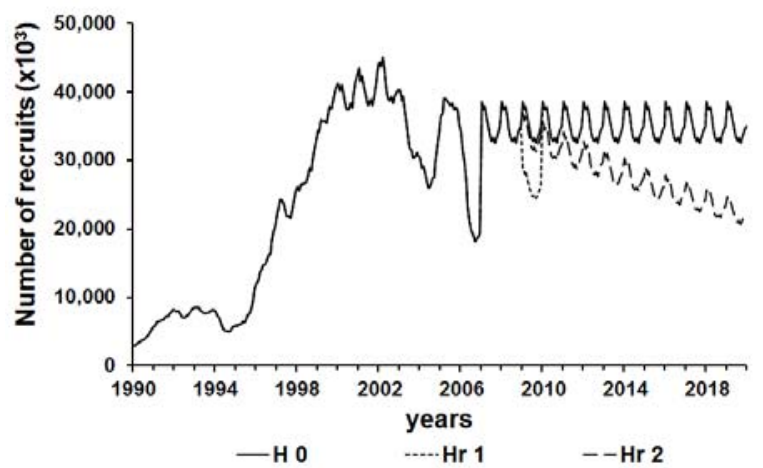

(c)

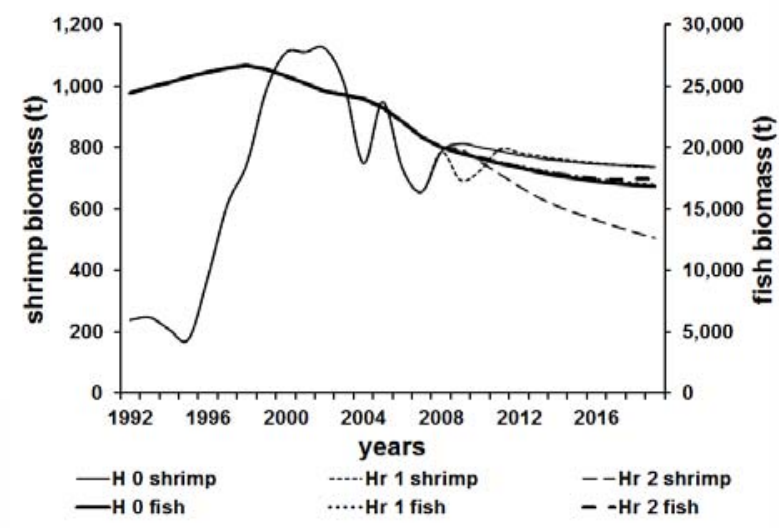

(e)

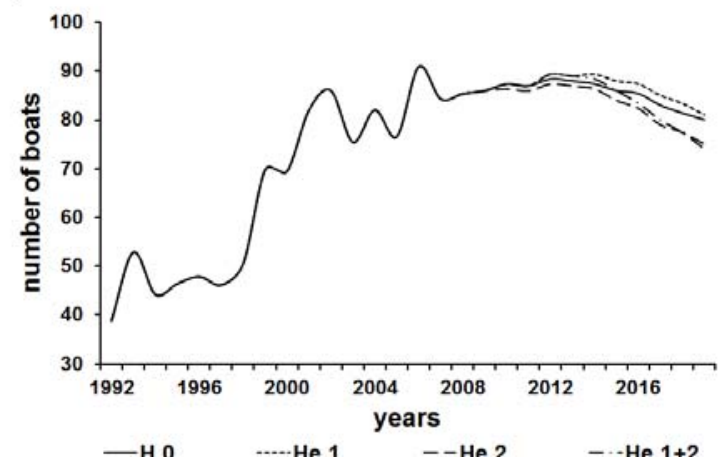

(g)

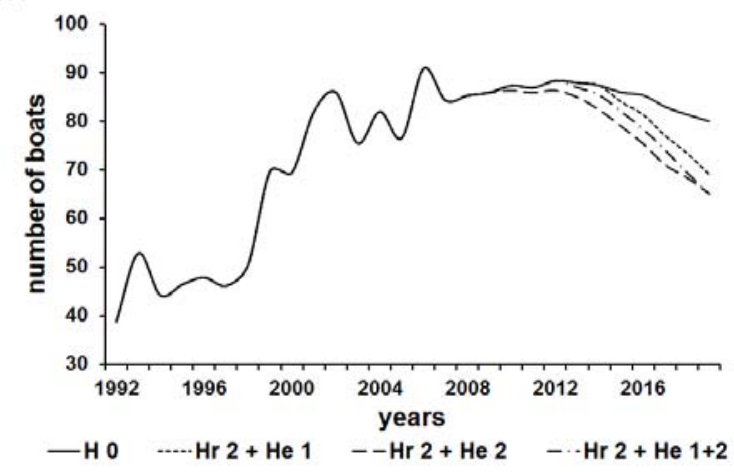

(b)

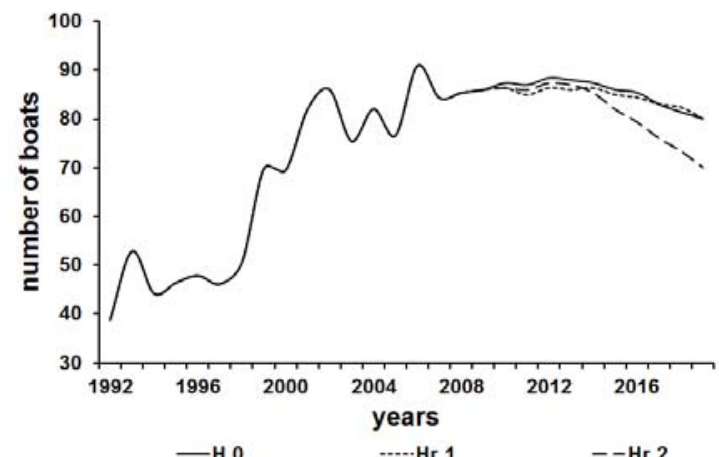

(d)
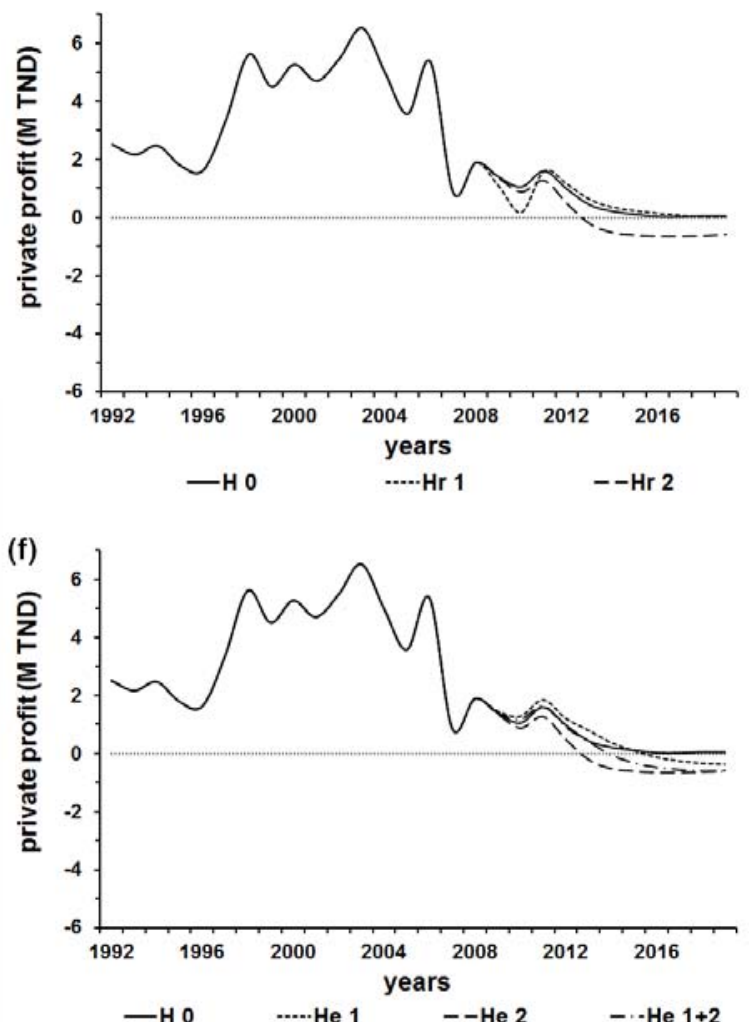

(h)

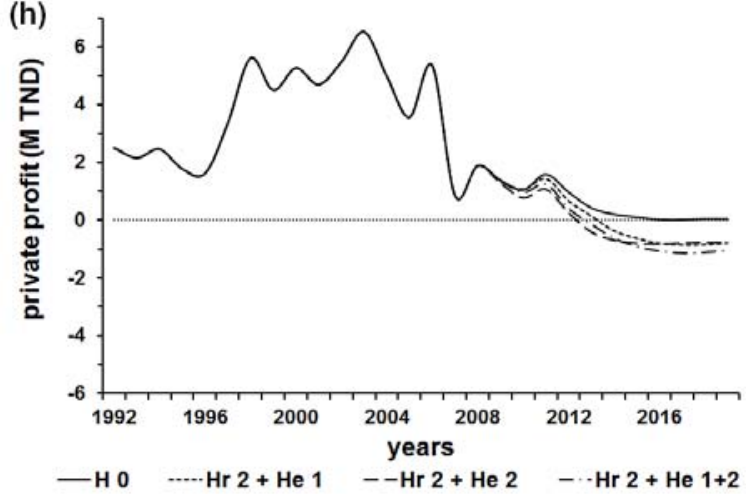

Figure 7: Responses to exogenous forcings. Effects on fishery resulting from the three recruitment situations: no change from 2009 to 2019 (H 0), a 25\% decrease in the number of recruits in 2009 (Hr 1) and a 4\% decrease per year in the number of recruits from 2009 ( $\mathrm{Hr} 2$ ): recruitment (a), active fleet (b), shrimp and fish biomass (c), private profit $(\mathrm{d})$. Effects resulting from four economic situations: the reference scenario is applied (H 0), the fuel price increase of 0.080 TND per year and the consumer price index increasing by 4 points per year (He 1), the export price index decreasing by 2 points per year (He 2) and these last two changes are both applied (He 
1+2): active fleet (e) and private profit (f). Effects resulting from the four previous economic situations combined with recruitment's situation $(\mathrm{Hr} 2)$ : active fleet $(\mathrm{g})$ and private profit $(\mathrm{h})$.

(a)

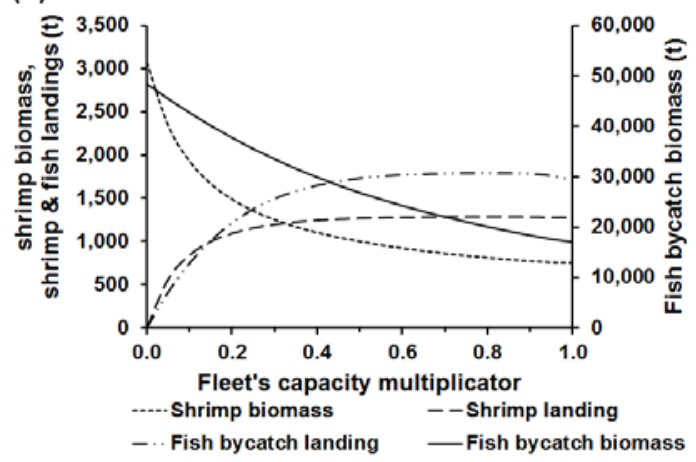

(c)

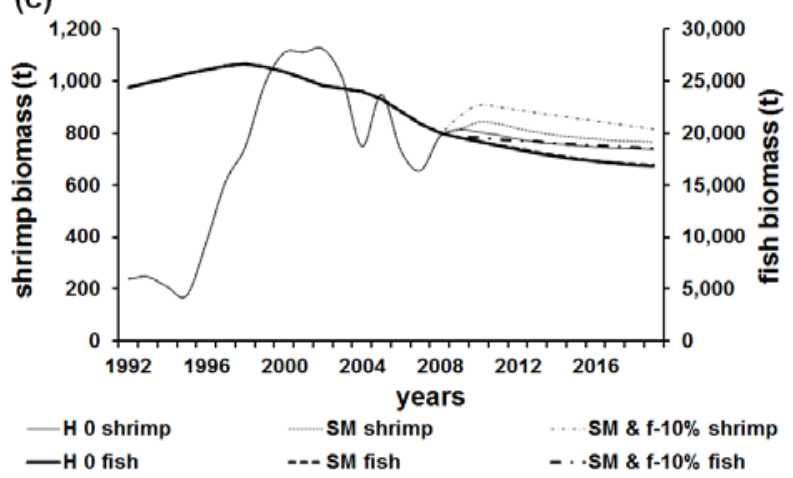

(b)

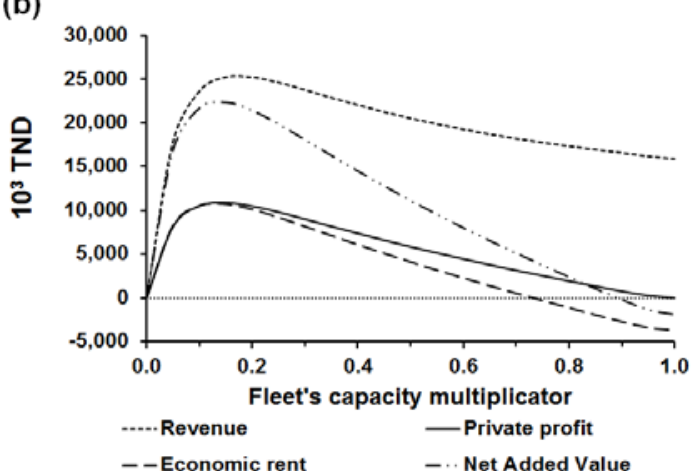

(d)

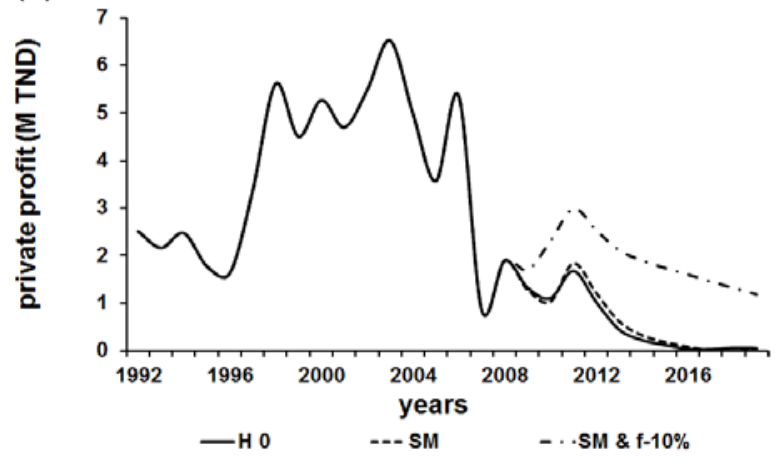

Figure 8: Impacts of fleet capacity regulation on the main biological indicators (a) and economic indicators (b) in the final year of the projected period and effects resulting from the adoption of $40 \mathrm{~mm}$ square mesh (SM), alone or combined with a $10 \%$ decrease in capacity (SM \& f-10\%) on the dynamics of shrimp and fish biomass (c) and the annual private profit $(\mathrm{d})$.

(a)

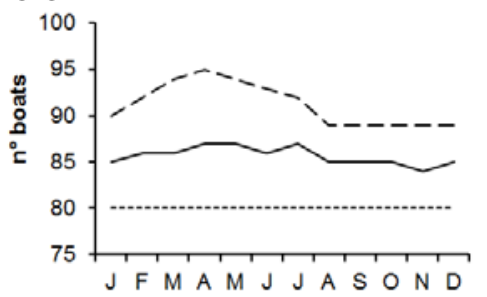

(d)

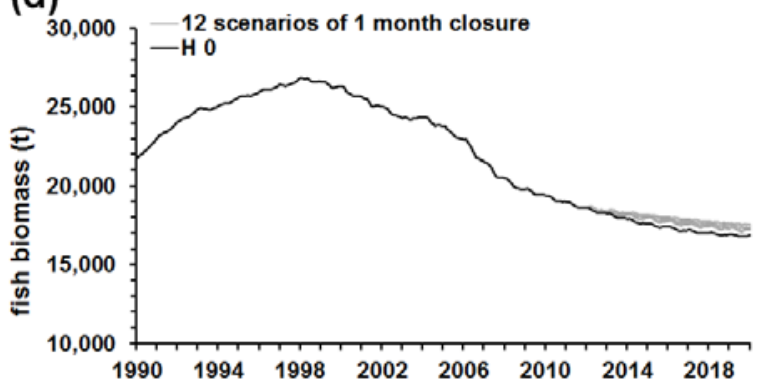

(b)

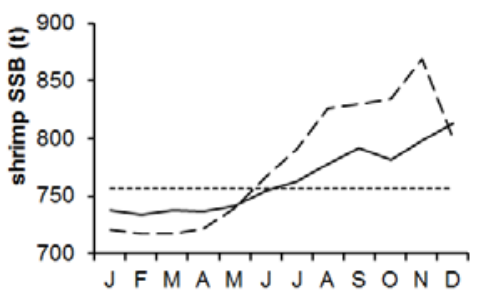

(c)

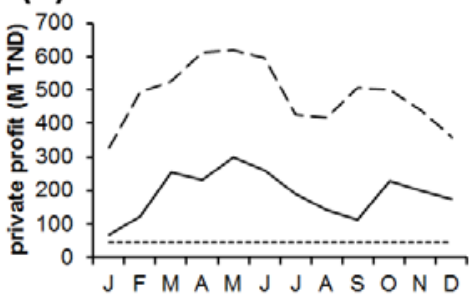

(e)

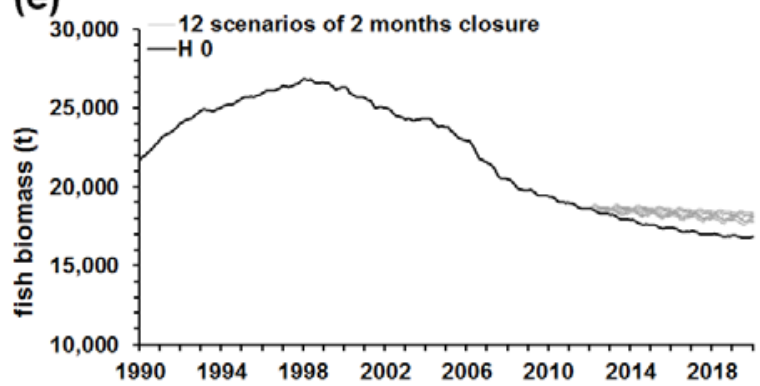

Figure 9: Effects of temporal closure on the main indicators at the end of projection period, no closure (dotted line), one month closure (solid line), two month closure (dashed line); annual mean of fleet capacity (a), standing stock biomass of shrimp (b), annual private profit (c) and effects on the dynamic of the standing stock biomass of fish in the case of a one month closure (d) and a two months closure (e). 
(a)

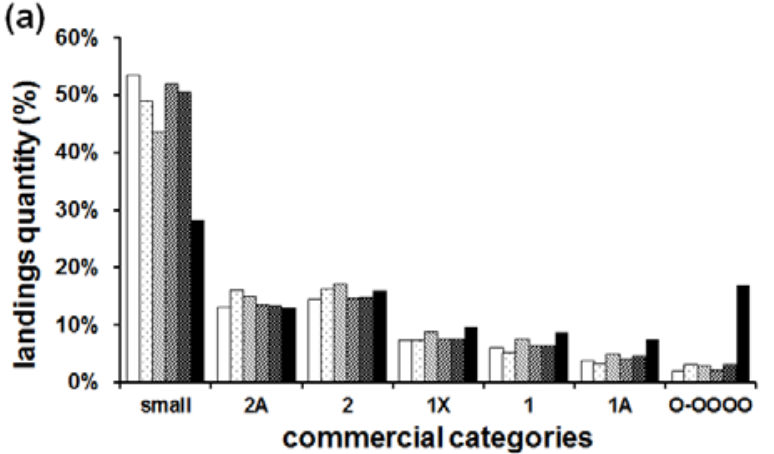

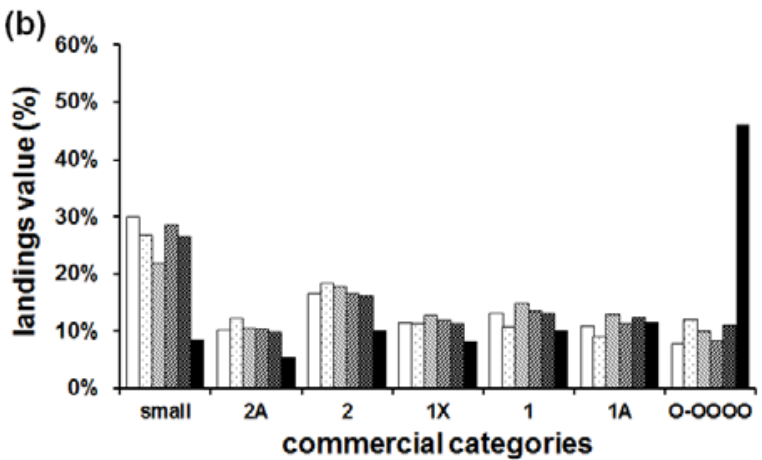

$\square \mathrm{H} 0 \square \mathrm{SM} \quad 0 \mathrm{SM} \& \mathrm{f}-10 \%$ ॠ

Figure 10: Effects of some mitigation measures on distribution per commercial categories of the shrimp catch, in quantity (a) and in value (b).

(a)

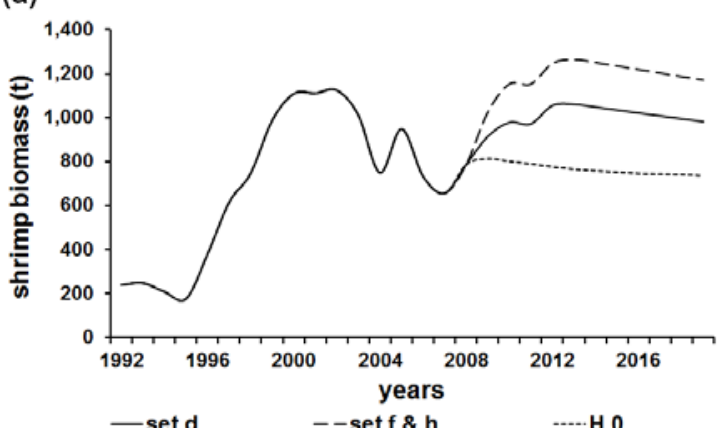

(c)

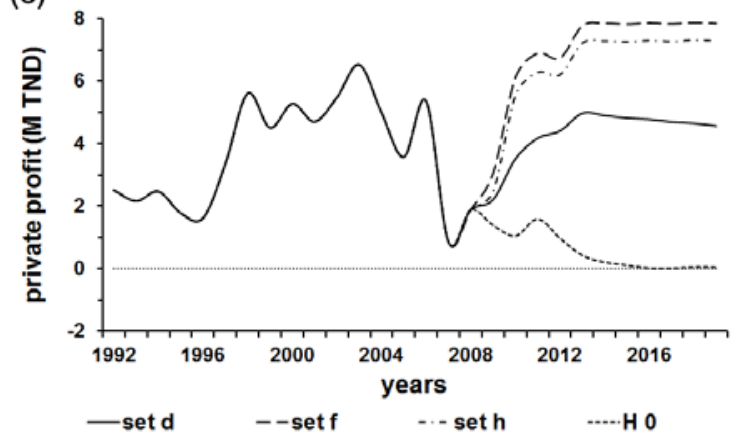

(e)

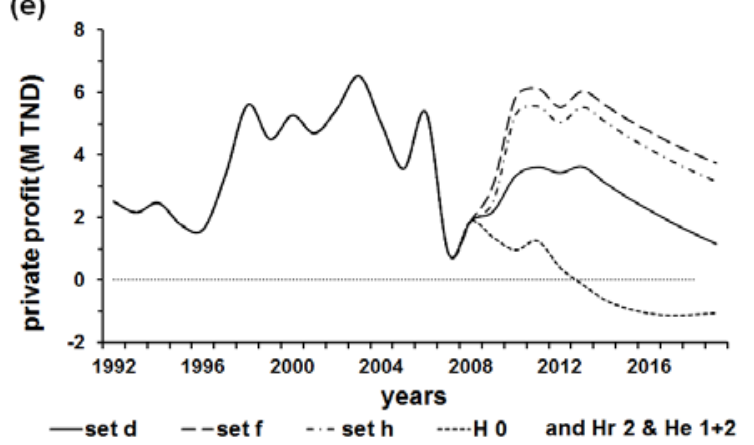

(b)

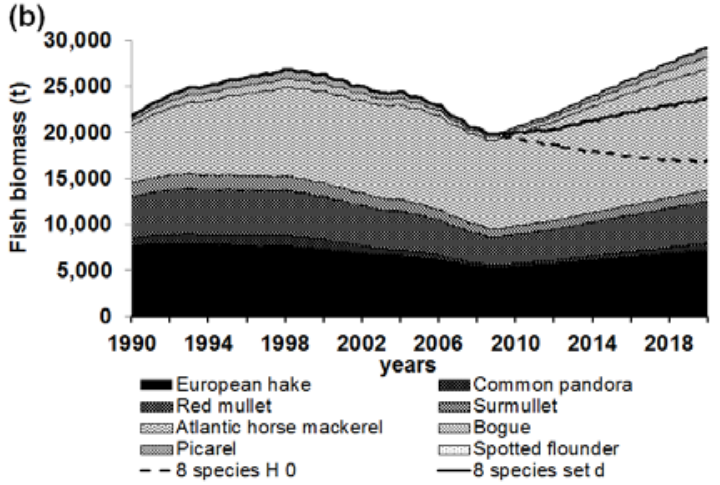

(d)

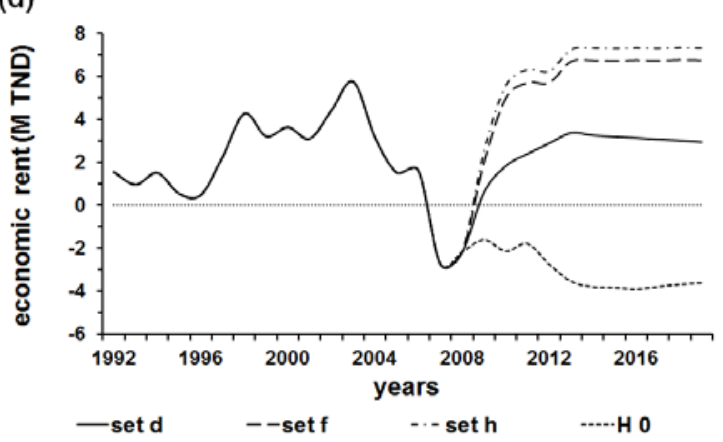

(f)

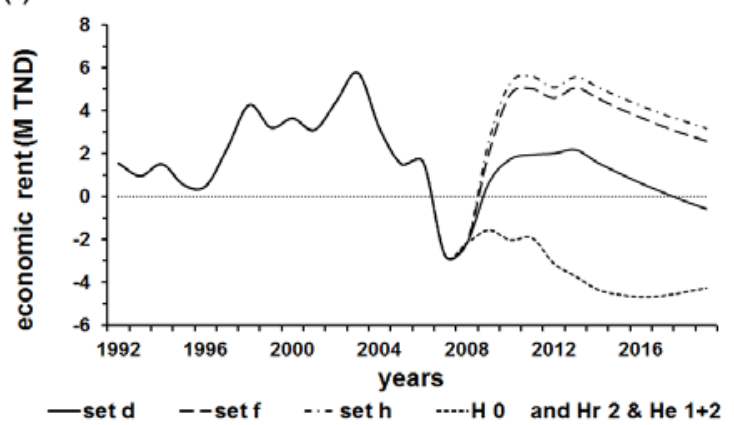

Figure 11: Biological and economic responses to sets of measures including square mesh, a fishing closure in May-June, reducing capacity by $25 \%$, total removal of biological recovery tax and a fuel subsidy by $20 \%$ (set d), square mesh, a fishing closure in May-June, reducing capacity by $50 \%$, total removal of biological recovery tax and a fuel subsidy of $20 \%$ (set f) and square mesh, a fishing closure in May-June, reducing capacity by $50 \%$, complete removal of biological recovery tax and of fuel subsidy (set $\mathrm{h}$ ): annual mean shrimp biomass (a), annual mean fish biomass detailed for sets $\mathrm{f}$ and $\mathrm{h}$ and global for set $\mathrm{d}(\mathrm{b})$, annual private profit $(\mathrm{c})$ and annual economic rent (d); economic responses resulting of exogenous forces in the cases of set $d, f$ and $h$ : annual private profit (e) and annual economic rent (f). 


\section{Tables}

Table 1: Spanish commercial category definitions and prices paid to the fishers in 2009-2010 for deep-water rose shrimp (source, export companies).

\begin{tabular}{lcccccc}
\hline Category & \multicolumn{2}{c}{ Price } & $\begin{array}{c}\text { Shrimps } \\
\text { ind.kg }\end{array}$ & $\begin{array}{c}\text { weight } \\
(\mathrm{g})\end{array}$ & $\begin{array}{c}\text { Male CL } \\
(\mathrm{mm})\end{array}$ & $\begin{array}{c}\text { Female CL } \\
(\mathrm{mm})\end{array}$ \\
\hline OOOO & 52.500 & $(38.91)$ & {$[58$ or less } & {$[17.24$ or more } & - & {$[33.17$, or more } \\
OOO & 42.000 & $(31.12)$ & {$[65,58[$} & {$[15.38,17.24[$} & {$[32.69$ or more } & {$[31.68,33.17[$} \\
OO & 38.000 & $(28.16)$ & {$[68,65[$} & {$[14.70,15.38[$} & {$[32.09,32.69[$} & {$[31.11,31.68[$} \\
O & 24.000 & $(17.79)$ & {$[80,65[$} & {$[12.50,14.70[$} & {$[29.99,32.09[$} & {$[29.14,31.11[$} \\
1A & 20.000 & $(14.81)$ & {$[90,80[$} & {$[11.11,12.50[$} & {$[28.56,29.99[$} & {$[27.79,29.14[$} \\
1 & 15.000 & $(11.12)$ & {$[100,90[$} & {$[10.00,11.11[$} & {$[27.34,28.56[$} & {$[26.63,27.79[$} \\
1X & 11.000 & $(8.15)$ & {$[110,100[$} & {$[9.09,10.00[$} & {$[26.28,27.34[$} & {$[25.63,26.63[$} \\
2 & 8.000 & $(5.93)$ & {$[130,110[$} & {$[7.69,9.09[$} & {$[24.52,26.28[$} & {$[23.96,25.63[$} \\
2A & 5.410 & $(4.01)$ & {$[150,130[$} & {$[6.57,7.69[$} & {$[23.11,24.52[$} & {$[22.62,23.96[$} \\
Small & 3.900 & $(2.89)$ & $>151$ & $<6.57$ & $<23.11$ & $<22.62$ \\
\hline
\end{tabular}

Table 2: Biological parameters of the deep-water rose shrimp used in the model. (CL : carapace length).

\begin{tabular}{|c|c|c|}
\hline Parameters & male & sources \\
\hline \multicolumn{3}{|l|}{ Growth parameters : } \\
\hline $\mathrm{LC}_{\infty}$ & $34.3 \mathrm{~mm} \mathrm{CL}$ & (Ragonese et al., 2004) \\
\hline $\mathrm{K}$ & 0.73 year $^{-1}$ & (Ragonese et al., 2004) \\
\hline \multicolumn{3}{|c|}{ Weight $(\mathrm{kg})$ length $(\mathrm{mm} \mathrm{CL})$ relationship : } \\
\hline Constant & 0.00345 & (Ben Meriem et al., 2010) \\
\hline Exponent & 2.4096 & (Ben Meriem et al., 2010) \\
\hline Natural mortality (M) & 1.05 year $^{-1}$ & 1.20 year $^{-1} \quad$ (Ben Meriem et al., 2010) \\
\hline Size at first maturity & $13.65 \mathrm{~mm} \mathrm{CL}$ & $20.85 \mathrm{~mm} \mathrm{CL}$ (Ben Meriem et al., 2010) \\
\hline
\end{tabular}

Table 3: Main costs used in the model extracted from economic surveys (values of the period 2009-2010).

\begin{tabular}{|c|c|c|c|c|c|c|c|}
\hline \multirow[t]{2}{*}{ Designation } & \multicolumn{2}{|c|}{ Costs per year } & \multicolumn{2}{|c|}{$\begin{array}{c}\text { Costs per day at } \\
\text { sea }\end{array}$} & \multicolumn{2}{|c|}{$\begin{array}{l}\text { Costs per kg of } \\
\text { catch }\end{array}$} & \multirow[t]{2}{*}{$\begin{array}{l}\text { Costs on the } \\
\text { catch value }\end{array}$} \\
\hline & (TND) & (USD) & (TND) & (USD) & $(\mathrm{TND})$ & (USD) & \\
\hline Insurance & 4,000 & $(2,964)$ & & & & & \\
\hline Mooring cost & 2,280 & $(1,690)$ & & & & & \\
\hline Hull's maintenance & 4,500 & $(3,335)$ & & & & & \\
\hline Engine maintenance & 6,500 & $(4,817)$ & & & & & \\
\hline maintenance and replacement of electronic equipment & 3,000 & $(2,223)$ & & & & & \\
\hline maintenance and replacement of fishing equipment & 15,000 & $(11,116)$ & & & & & \\
\hline Gasoil (1 200 I per day at sea) & & & 850 & $(630)$ & & & \\
\hline Oil, lubricant & & & 14.180 & $(10.51)$ & & & \\
\hline Supplies & & & 250 & $(185)$ & & & \\
\hline Refrigerant and/or ice & & & 2.523 & $(1.87)$ & & & \\
\hline Processing and packaging & & & & & 0.130 & $(0.10)$ & \\
\hline Tax of Biological Recovery on production for exportation & & & & & & & $2 \%$ \\
\hline Tax of Biological Recovery on production for national & & & & & & & $1 \%$ \\
\hline market & & & & & & & \\
\hline Labor revenue (crew) & & & & & & & $50 \%$ \\
\hline Owner's revenue & & & & & & & $50 \%$ \\
\hline
\end{tabular}


Table 4: Impact of combined measures on the main biological and economic indicators in the last year of the projected period and response to recruitment and economic forces. The measures include a period of closure and a level of reducing fleet capacity (by $25 \%$ or $50 \%$ ) and a set of three measures composed of the adoption of square mesh, removal of the tax on biological recovery and decrease in fuel subsidy from $30 \%$ to $20 \%$ (c, d, e, f, g) or removal of this subsidy (h and i). The response to exogenous forces (decrease in recruitment of $4 \%$ per annum, consumer price index increasing by 4 points per annum, decrease of export price index by 2 points per annum) is tested in two cases ( $g$ and i). Finally, the set h, reducing the capacity by $82.5 \%$ instead of $50 \%$ (j).

To put these results into perspective, the values at the end of calibration period $\left(\mathrm{a}_{0}\right)$, the results of the reference scenario $\mathrm{H} 0$ (a) and of the scenario of applying GFCM's measures (b) are indicated.

\begin{tabular}{|c|c|c|c|c|c|c|c|c|c|c|c|}
\hline & \multirow{2}{*}{$\begin{array}{c}\text { Fleet's } \\
\text { capacity } \\
\text { (boats) }\end{array}$} & \multirow{2}{*}{$\begin{array}{c}\text { Shrimp's } \\
\text { biomass } \\
\text { (t) }\end{array}$} & \multirow{2}{*}{$\begin{array}{c}\text { Fish's } \\
\text { biomass } \\
\text { (t) }\end{array}$} & \multicolumn{2}{|c|}{ Private profit } & \multicolumn{2}{|c|}{ State's revenue } & \multicolumn{2}{|c|}{ Added value } & \multicolumn{2}{|c|}{ Economic rent } \\
\hline & & & & $\left(10^{3} \mathrm{TND}\right)$ & $\left(10^{3}\right.$ USD) & $\left(10^{3} \mathrm{TND}\right)$ & $\left(10^{3}\right.$ USD $)$ & $\left(10^{3} \mathrm{TND}\right)$ & $\left(10^{3}\right.$ USD) & $\left(10^{3} \mathrm{TND}\right)$ & $\left(10^{3}\right.$ USD $)$ \\
\hline $\mathrm{a}_{0}$ ) End of calibration period (2008) & 85.3 & 835 & 19,798 & 1,880 & $(1,393)$ & $-6,625$ & $(-4,910)$ & 2,469 & $(1,830)$ & $-2,169$ & $(-1,607)$ \\
\hline a) Reference scenario $(\mathrm{H} 0)$ & 80.0 & 756 & 16,850 & 52 & (39) & $-3,747$ & $(-2,777)$ & $-1,788$ & $(-1,325)$ & $-3,618$ & $(-2,681)$ \\
\hline b) Square mesh, $10 \%$ fleet capacity reduction & 76.4 & 834 & 18,505 & 1,181 & (875) & $-3,535$ & $(-2,620)$ & 637 & (472) & $-2,281$ & $(-1,690)$ \\
\hline c) Panel, Closure Dec.-Jan., capacity - $25 \%$ & 63.6 & 977 & 22,880 & 3,818 & $(2,829)$ & $-1,822$ & $(-1,350)$ & 7,087 & $(5,252)$ & 2,057 & $(1,524)$ \\
\hline d) Panel, Closure May-June, capacity - $25 \%$ & 63.6 & 957 & 23,636 & 4,563 & $(3,382)$ & $-1,685$ & $(-1,249)$ & 8,714 & $(6,458)$ & 2,939 & $(2,178)$ \\
\hline e) Panel, Closure Dec.-Jan., capacity - 50\% & 42.4 & 1,141 & 28,588 & 7,117 & $(5,274)$ & $-1,214$ & $(-900)$ & 13,868 & $(10,277)$ & 5,943 & $(4,404)$ \\
\hline f) Panel, Closure May-June, capacity - 50\% & 42.4 & 1,151 & 29,295 & 7,839 & $(5,809)$ & $-1,124$ & $(-833)$ & 15,403 & $(11,415)$ & 6,756 & $(5,007)$ \\
\hline g) Set (f) and exogenous forcing & 42.4 & 740 & 29,295 & 3,738 & $(2,770)$ & $-1,181$ & $(-875)$ & 15,050 & $(11,153)$ & 2,587 & $(1,917)$ \\
\hline h) Set (f) deleting fuel's subsidy & 42.4 & 1,151 & 29,295 & 7,277 & $(5,393)$ & 0.2 & (0) & 15,403 & $(11,415)$ & 7,318 & $(5,423)$ \\
\hline i) Set (h) and exogenous forcing & 42.4 & 740 & 29,295 & 3,147 & $(2,332)$ & 0.2 & (0) & 7,143 & $(5,293)$ & 3,178 & $(2,355)$ \\
\hline j) Set (h) with capacity - $82.5 \%$ & 14.8 & 1,779 & 40,307 & 11,174 & $(8,281)$ & 0.1 & (0) & 22,646 & $(16,782)$ & 11,188 & $(8,291)$ \\
\hline
\end{tabular}

